\title{
Integrating fisheries management into sustainable development planning
}

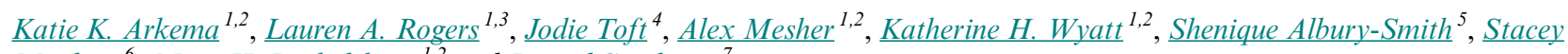 \\ Moultrie $^{6}$, Mary H. Ruckelshaus ${ }^{1,2}$ and Jameal Samhouri ${ }^{7}$
}

\begin{abstract}
Scientific understanding of coupled social-ecological systems has grown considerably in recent years, especially for fisheries and ocean management. However, few studies test the utility of approaches that capture multiple interactions between people and ecosystems within a real-world planning process. We developed a set of quantitative models that estimate catch and revenue from the Caribbean spiny lobster (Panulirus argus) fishery as a function of coastal habitat extent and quality. We applied the models iteratively, with input from stakeholders, to assess fisheries outcomes of alternative scenarios for integrated coastal zone management in Belize and sustainable development planning in The Bahamas. We found that integrated management reduces risk to nursery habitats from multiple coastal and marine activities and increases lobster catch and revenue by large margins. In Belize, siting activities such as marine transportation and tourism development to explicitly reduce risk to nursery and adult habitats enhanced returns from the lobster fishery. In The Bahamas, strategic investments in economic development that focused on updating existing infrastructure, such as roads, rather than expanding the footprint of development, increased the catch of lobster by approximately half again as much relative to a business as usual scenario. Our findings show how models that link spatial information about coastal habitats and the dynamics of a key fishery can inform expected change in catch and revenue as a result of coastal management. In addition to strengthening stakeholder understanding of social-ecological relationships and highlighting national-scale outcomes of regional development decisions, modeled results allowed us to transparently and effectively improve coastal plans to achieve the goals of the citizens and governments of Belize and The Bahamas. These cases illustrate how models that account for relationships between development, nursery habitats, and fishing catch and revenue can elevate the importance of fisheries management in national development decisions.
\end{abstract}

Key Words: Belize; ecosystem-based management; ecosystem services; fisheries; integrated coastal zone management; nursery habitat; participatory process; stakeholder engagement; sustainable development; The Bahamas

\section{INTRODUCTION}

Globally, the human population is fast approaching 10 billion, with demand for ocean resources, such as fisheries, growing exponentially (Food and Agriculture Organization of the United Nations 2014). Increasing intensity and diversity of human activities in coastal zones threaten the long-term sustainability of ecosystems (Halpern et al. 2008) and the livelihoods, sustenance, and recreational enjoyment they provide to people. In response, calls for integrated ocean management that recognizes "coupled social-ecological systems" have grown in recent years (Liu et al. 2007, Ostrom 2009, Kohler et al. 2017, Levin and Poe 2017). However, fisheries management typically is conducted separately from development planning, and quantitative approaches that capture interactions among ocean activities, ecosystems, and human well-being can be time intensive and resource prohibitive. Furthermore, overly complex models may be difficult to use within participatory processes, which are a hallmark of effective development planning and natural resource management (Pomeroy and Douvere 2008, Torres and Hanley 2016, Christie et al. 2017). For integrated marine management to become the norm, coastal, marine, and fisheries managers need demonstrations that it is technically and socially feasible, and that it can lead to better outcomes.

Fisheries provide numerous benefits to people, including sustenance, income, recreation, and important cultural values such as sense of place, identity, and purpose. However, managing seafood harvest is often the responsibility of a single fisheries department or agency. Although the fisheries department or agency may have a mandate to maintain species populations and fishers' livelihoods, they often lack jurisdiction over factors that influence fish abundance, such as development pressures and pollution. The siloed nature of fisheries management can be particularly problematic in the Caribbean, where iconic and economically important species, including lobster (Panulirus argus), conch (Lobatus gigas), and reef fishes, rely on vulnerable coastal habitats for spawning and rearing (Harborne et al. 2006, Fanning et al. 2011). These habitats also provide benefits beyond fisheries, such as protection from sea-level rise and storm hazards, tourism value, and carbon storage and sequestration (Mumby et al. 2008, Barbier et al. 2011, Arkema et al. 2013, Beck et al. 2018). Maintaining fisheries alongside other benefits requires a broader ecosystem perspective of spatially explicit connections across biophysical and human subsystems.

To support calls for integrated and ecosystem-based management of fisheries and oceans, scientists have developed a variety of approaches that incorporate information about habitats, economically important species, and people. These approaches range from complex models, which link physical components, the food web, and fishing fleets (Fulton et al. 2014, Masi et al. 2017), to simple frameworks, e.g., FishPath, designed to guide management in data poor environments, but without explicitly modeling the system (Dowling et al. 2016, McDonald et al. 2017). Although managers and stakeholders often know that coastal ecosystems, such as mangroves, seagrass, and corals, provide habitat for marine organisms, explicitly accounting for them in decision making requires understanding the influence of

${ }^{1}$ Natural Capital Project, Woods Institute for the Environment, Stanford University, ${ }^{2}$ School of Environmental and Forest Sciences, University of Washington, ${ }^{3}$ Alaska Fisheries Science Center, National Marine Fisheries Service, National Oceanic and Atmospheric Administration, ${ }^{4}$ Puget Sound Restoration Fund, ${ }^{5}$ The Nature Conservancy Bahamas Program, ${ }^{6} \mathrm{SEV}$ Consulting Group, ${ }^{7}$ Conservation Biology Division, Northwest Fisheries Science Center, National Marine Fisheries Service, National Oceanic and Atmospheric Administration 
Fig. 1. Lobster habitat in each of nine planning regions in Belize (a) and by ecoregion in The Bahamas (b). Blue indicates depth gradient.
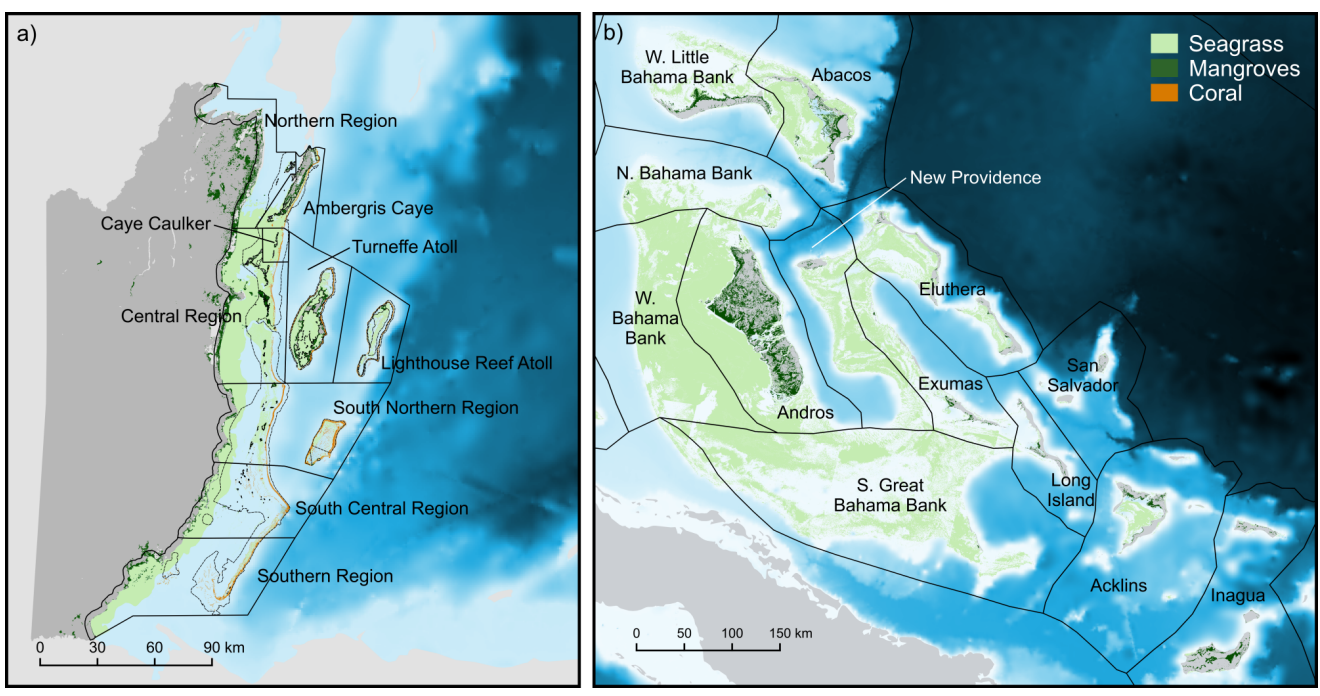

particular actions on specific habitat areas, the links between those habitat areas and the dynamics of exploited populations, and the outcome for broader management objectives, e.g., how much will construction of new coastal roads impact fish habitat and, thus, catch and revenue? Models of intermediate complexity, with simplified representations of the biophysical system, can be crafted relatively quickly, have reasonable data requirements, and be used to inform strategic evaluation of management scenarios with stakeholders for broad integrated planning (Plagányi et al. 2014, Collie et al. 2016).

Another key to sustainable and integrated management of oceans and coasts is effective engagement of stakeholders (Cook et al. 2013, Arkema et al. 2015, Clark et al. 2016a). Processes that incorporate active participation, elicit local knowledge and potential solutions, foster transparency, and recognize the right of stakeholders to be involved in decision making are more likely to be supported by key actors and meet multiple management goals (Reed 2008, Ostrom 2009, Gopnik et al. 2012, Basurto et al. 2016, Fujita et al. 2017). Models of social-ecological systems can facilitate participation by incorporating stakeholder perspectives, especially if they are transparent and applied iteratively within the timeline of a policy process. Maps and infographics can be used for stakeholders to explicitly express knowledge and interests, increasing specificity of choice outcomes, and clarifying ostensible conflicts of interest among objectives (Ruckelshaus et al. 2015, Kenter et al. 2016, Arkema and Ruckelshaus 2017). Skillful use of relatively simple models has the potential to support coproduction of knowledge among local communities, decision makers, and scientists, which is an important element of collaborative processes that promotes equity of outcomes, legitimacy of planning, and agency across stakeholders (Clark et al. 2016b, Posner et al. 2016).

We present two case studies that demonstrate how models linking coastal habitat and fisheries can be constructed with stakeholder engagement to inform and enhance possible outcomes from both fishery management and development planning. Specifically, we highlight how management of Caribbean spiny lobster (Panulirus argus) was incorporated into the design of (1) an integrated coastal zone management (ICZM) plan in Belize and (2) a sustainable development master plan in The Bahamas. We focus on spiny lobster because it is one of the most important and highest value export fisheries in the region. The lobster fishery has also suffered declines in landings since the mid-1990s because of overfishing and habitat loss (Ehrhardt et al. 2011, Fujita et al. 2019), as the pace of development has grown throughout the Caribbean and Latin America. In both countries, we used simple models connected by scenarios of change in coastal habitats to understand how alternative management and development decisions could influence the fishery. During the planning processes, two main research and management questions emerged: (1) How do lobster habitat, catch, and revenue change under alternative future management scenarios? (2) How do catch and revenue vary spatially as a function of spatial variation in lobster habitat? We share modeling results within the context of the interactive stakeholder engagement and decision-making processes to answer a third question: (3) How were the results of our analysis specifically used to inform integrated management in each country? Although focused on the Caribbean, the results we share provide insights and examples for how other countries from around the world can elevate fisheries management and better inform development planning through models linking habitat, fisheries, and management of multiple coastal sectors.

\section{METHODS}

To assess fisheries outcomes of alternative scenarios for coastal zone management in Belize and development planning in The Bahamas, we combined quantitative modeling and stakeholder engagement. For each country, we first describe the planning context, stakeholder engagement process, and management scenarios. Second, we provide an overview of the lobster models. Third, we describe how we assessed changes in lobster habitat under each alternative management scenario, and finally, we describe how we estimated landings and export value for each scenario (Fig. A1.1 in Appendix 1). 
Table 1. Description of stakeholder-driven development scenarios for integrated coastal zone management in Belize and sustainable development of Andros Island in The Bahamas.

\begin{tabular}{|c|c|c|}
\hline Country & Scenario & Description \\
\hline \multirow[t]{3}{*}{ Belize } & Conservation & $\begin{array}{l}\text { Represents a vision of long-term ecosystem health through sustainable use and investment in } \\
\text { conservation, limiting new coastal development, and reducing space for extractive activities. }\end{array}$ \\
\hline & Development & $\begin{array}{l}\text { Presents a vision of rapid economic development, prioritizing natural resource utilization, and urban } \\
\text { expansion over long-term sustainable use and future benefits from nature. }\end{array}$ \\
\hline & Informed management & $\begin{array}{l}\text { Combines strong conservation goals with current and future needs for coastal development and } \\
\text { marine uses; was refined over time through iterations of ecosystem service modeling and stakeholder } \\
\text { review. }\end{array}$ \\
\hline \multirow[t]{4}{*}{ The Bahamas } & Business as usual & $\begin{array}{l}\text { Represents a future similar to the current situation with little investment in new infrastructure, } \\
\text { educational opportunities, or development. }\end{array}$ \\
\hline & Conservation & $\begin{array}{l}\text { Gives priority to ecosystem health and protection of habitats and species, such as ratification of a } \\
\text { national park for the Andros Barrier Reef, rather than economic development. }\end{array}$ \\
\hline & Intensive development & $\begin{array}{l}\text { Gives priority to major economic development, such as a cruise ship port and luxury housing } \\
\text { developments, rather than ecosystem health and protection of habitats and species. }\end{array}$ \\
\hline & Sustainable prosperity & $\begin{array}{l}\text { Combines human development and conservation goals by investing in critical infrastructure, such as } \\
\text { road improvements and daily ferries, and education to achieve a nature-based economy that can be } \\
\text { sustained over time. This scenario was refined over time through iterations of ecosystem service } \\
\text { modeling and stakeholder review. }\end{array}$ \\
\hline
\end{tabular}

\section{Belize}

The coast of Belize encompasses hundreds of kilometers of mangrove forests, extensive seagrass beds, the largest continuous coral reef in the Western Hemisphere, and more than 300 cayes (Fig. 1a). These habitats support diverse assemblages of estuarine and marine species and provide numerous benefits to the Belizean people, $35 \%$ of whom live along the coast (Belize Coastal Zone Management Authority and Institute 2016). Benefits include world-renowned snorkeling and diving that draw more than 400,000 overnight tourists and 1,000,000 cruise passengers annually (Belize Tourism Board 2017), natural protection from flooding and erosion, and abundant fisheries that support coastal communities (Cooper et al. 2009).

The spiny lobster fishery plays an important role in the livelihoods of Belizeans as the largest wild capture fishery in the country. For example, the more than $277,000 \mathrm{~kg}(611,000 \mathrm{lb}$.) of lobster tail landed in 2011 generated nearly BZD 17 million in earnings (Belize Fisheries Department 2012). Although lobster landings have remained relatively stable since the 1990 s, the number of fishers has gradually increased since the early 2000s. By law, fishing cooperatives have the exclusive right to export lobster, allowing export revenues to stay within the fishing community (Huitric 2005). The Belize Fisheries Department collects biological, e.g., carapace lengths and tail weights, and catch per unit effort (CPUE) data that are used in setting regulations on minimum size and weight, restricting gear, prohibiting retention of berried females, and establishing seasonal and area closures. However, limited capacity in the fisheries department has made enforcement of these regulations difficult (Belize Fisheries Department 2012). In recent years, Belize has pursued a variety of innovative fisheries (Fujita et al. 2017, 2019) and integrated management approaches (Arkema et al. 2015).

\section{Integrated coastal zone management in Belize}

Belize's coastal and marine ecosystem is under increasing pressure, not only from fishing but also from development, aquaculture, marine transportation, and other activities in the coastal zone (Arkema et al. 2014). To provide guidance about where and how to engage in ocean and coastal activities to achieve conservation and development goals (Government of Belize 2000), the Government of Belize set out to design the nation's first ICZM plan. In 2010, the Coastal Zone Management Authority and Institute (CZMAI) partnered with the Natural Capital Project to integrate ecosystem services and stakeholder engagement in the plan's design (Arkema and Ruckelshaus 2017). Together, we used several models of ecosystem services to assess tourism, fisheries, and coastal protection objectives under three future scenarios for zoning human activities across nine planning regions (Fig. 1a, Table 1).

We conducted a stakeholder engagement process that included more than 50 public and Coastal Advisory Committee meetings for the 9 coastal planning regions over 6 years. Early in the process, CZMAI elicited input from stakeholders on their ideas about the future of the Belize coastal zone and used participatory mapping approaches to gather local knowledge about current and future coastal zone activities (Arkema et al. 2015, Arkema and Ruckelshaus 2017, Verutes et al. 2017). During subsequent meetings, CZMAI and the Natural Capital Project shared digitized versions of the zoning scenarios composed of elements suggested by stakeholders. The three scenarios varied in the distribution and intensity of eight activities identified by stakeholders and government agencies: fisheries, aquaculture, coastal development, oil and gas exploration, dredging, marine transportation, recreation, and agricultural runoff (Table 1; Arkema et al. 2014, 2015, Arkema and Ruckelshaus 2017, Verutes et al. 2017). We also shared results from the ecosystem service models, including catch and revenue of lobster, and gathered stakeholder input.

\section{Model overview}

To estimate how changes in habitat influence catch and revenue from the lobster fishery, we developed a model that incorporates life history, recruitment, migration, harvest, mortality, and habitat dependencies and produces estimates of catch as landings and export value at national and subregional scales (Arkema et al. 2015, Ward et al. 2018; Table A1.1 in Appendix 1). The 
population model is spatially explicit and age structured with a Beverton-Holt spawner-recruitment relationship. By linking recruitment or survival to habitat availability, the model can be used to assess how changes in habitat could affect productivity of the stock and resulting catch. Full model documentation, including inputs and data sources, is in our Appendix 1 and the supplement of Arkema et al. (2015). The model is also available for download as part of the InVEST suite of ecosystem services models (Sharp et al. 2018).

For Belize, we modeled the lobster population as nine regional, linked age-structured subpopulations where age-specific survival is affected by habitat availability. The subpopulations correspond to the nine planning regions for the Belize ICZM plan (Fig. A1.2 in Appendix 1). We quantified catch and revenue in 2010 (current scenario) and for the three future scenarios, and we used catch and CPUE time series, ranging from 1932 to 2010, to fit model parameters including harvest rate and stock-recruit parameters (Table A1.2 in Appendix 1). We drew other model parameters from existing studies in the region to ensure that the model best represents the Belizean population. The parameterized model was run forward to 2025 for each of the three scenarios.

We included nursery and adult habitat in the analysis (Fig. 1a). Mangrove and seagrass are used as nursery habitat by larvae and juveniles, and coral reefs provide adult habitat (Butler and Herrnkind 2000). The subpopulations were connected via immigration as lobster move from mangroves and seagrass in larval and juvenile life stages (ages 0-2) to coral reefs as they enter adult life stages (ages $3+$ ); survival was dependent on availability of juvenile and adult habitat. Larvae were assumed to mix across all regions during their extended pelagic period, then settle in nursery habitat in direct proportion to its availability across all regions, i.e., a region with $12 \%$ of nursery habitat received $12 \%$ of recruits (also see Garavelli et al. 2018). We based initial distribution of lobster in each age class on the extent of mangrove and seagrass (for larvae and juveniles) and coral reef (for adults) in each region (see Appendix 1 for additional details).

\section{Estimating risk to lobster habitat}

Spatial variation in nursery and adult habitat, and changes in habitats for the future scenarios, were modeled with the InVEST Habitat Risk Assessment (HRA) model (Dugan et al. 2011, Arkema et al. 2014, Wyatt et al. 2017, Sharp et al. 2018). Full details of the risk assessment and application of the HRA model in Belize can be found in Arkema et al. (2014). In short, the model is based on a classic risk assessment approach that incorporates information about exposure of habitats to human activities and the habitat-specific consequences of that exposure. Outputs of the model include maps depicting spatial variation in the cumulative risk of habitat degradation, which we in turn used to produce quantitative estimates of reduction in functional habitat for lobster.

In Belize, we used the model to understand where the eight types of human activities posed the greatest risk of degradation to coral, mangrove, and seagrass habitats in the current and three future scenarios (Arkema et al. 2014; Table 1). The locations of nursery, i.e., mangroves and seagrasses, and adult, i.e., coral reefs, habitats were identified using GIS data from field surveys and satellite imagery (see Arkema et al. 2014). The risk assessment results were then applied to estimate areas of coral, mangroves, and seagrass of sufficient quality to provide nursery and adult habitat for the lobster fishery. Habitat at high risk was assumed to no longer be functional for spiny lobster and was excluded from calculations of future habitat area; habitat at medium risk was assumed to be $50 \%$ functional, thus contributing half its area to future area calculations; and habitat at low risk was assumed to be fully functional (Arkema et al. 2015).

We used these coarse assumptions for four reasons: (1) information about the relationship between the impact of multiple activities and ecosystem structure and function is extremely limited (Halpern et al. 2008); (2) they are simple and transparent; (3) they were supported by CZMAI on the grounds that they wanted to follow a precautionary management approach; and (4) comparisons between modeled risk to mangroves and observed data on mangrove fragmentation suggest that medium- and high-risk areas for the current scenario align with regions where forests are fragmented (Arkema et al. 2014). Although the assumed relationships between categories of risk and area of functional habitat were appropriate for our work in the Caribbean, they are a source of uncertainty in our analyses (Bryant et al. 2018 and references therein) and a topic that deserves further research in studies aiming to ask how cumulative risk from human activities may affect habitat for fisheries such as the spiny lobster (Arkema et al. 2015).

\section{Modeling catch and revenue}

Catch was calculated as the exploitation rate applied to agespecific harvestable biomass. Exploitation rate was held constant to isolate the effects of changes in nursery and adult habitats from the scenarios. From catch, we calculated revenue as export value of lobster tails, defined as the product of the pounds of lobster tails exported and price per pound for exported lobster tails. The fisheries department provided limited information on spatial variation in catch ( $R$. Carcamo and M. Canto, personal communication, 2013). Although the fishing regions delineated by the department do not correspond to the ICZM planning regions and therefore preclude quantitative comparison, we compared qualitatively the areas of empirical highest catch to the areas of modeled highest catch.

\section{The Bahamas}

The marine and coastal ecosystems of the more than 700 islands in The Bahamas (Fig. 1b) provide habitat to a diversity of animals and plants and numerous benefits to the Bahamian people. Thousands of miles of beach, extensive sand flats, barrier and fringing reefs, and the highest density of blue holes in the world are home to many species, including turtles, flamingos (Phoenicopterus ruber), and coral reef fishes (Thurlow and Palmer 2007), and draw more than 6 million tourists annually (Ministry of Tourism 2016). Several commercial, recreational, and subsistence fisheries support livelihoods and provide sustenance to the Bahamian people (Hargreaves-Allen 2010, Moultrie et al. 2016).

The lobster fishery is the most valuable fishery in The Bahamas, accounting for more than $55 \%$ of landings by volume in 2014 , $90 \%$ of total Bahamian fishery exports from 2010 to 2015 , and part- and full-time employment to 9000 fishers as of 2016 (FishStatJ; Moultrie et al. 2016). The Bahamian Department of Marine Resources (DMR) is responsible for monitoring and managing the fishery and determined in 2012 that the population 
was not overexploited (Medley and Gittens 2012). DMR regulates the lobster fishery through gear restrictions, size limits for harvest, spatial and temporal closures, and permit requirements. Threats to the fishery include illegal, unreported, and unregulated fishing by domestic and foreign vessels and degradation of nursery habitat because of development. Recent research suggests that the lobster population of the western Bahamas receives more than it contributes to the broader regional larval pool; its stocks may not be limited by spawning population, but rather by recruitment potential, which is strongly influenced by the availability of nursery habitat (Kough et al. 2013). Because of its importance to the Bahamian economy and livelihoods, catch and revenue of lobster was one of the objectives for the Sustainable Development Master Plan for Andros Island (Government of The Bahamas 2017).

\section{Sustainable development planning on Andros Island}

Andros, the largest island in The Bahamas, is known for its diverse ecosystems and wealth of natural resources. In 2015, the Office of the Prime Minister embarked on an effort to create a 25-year sustainable development plan for Andros as part of a national development planning process, Vision2040. The goal of the plan was to address Androsians' development needs while ensuring the sustainability of commercial and sport-fishing industries, naturebased tourism activities, agriculture, and freshwater resources. In consultation with Androsians from each of the island's four districts, the Office of the Prime Minister, the Natural Capital Project, the University of The Bahamas, SEV Consulting Group, and the Nature Conservancy, with support from the InterAmerican Development Bank, developed four future development scenarios and compared these scenarios by modeling ecosystem services (Government of The Bahamas 2017).

The design of the alternative future development scenarios involved extensive stakeholder engagement to ensure diverse perspectives and interests were represented. We reached community members, civil society, and representatives of key industries such as fishing and tourism through public meetings, open houses, one-on-one visits to homes and businesses, and targeted meetings with local government officials and school groups. Similarly to the process in Belize, we used these meetings to understand the key management issues around seven stakeholder-identified human activities, i.e., development, dredging and mining, fisheries, forestry, nature-based tourism, agriculture, and transportation of goods and people by water; two other drivers of change, i.e., invasive species and sea-level rise; and designation and enforcement of protected areas. We used the information we elicited from stakeholders to design, along with a business as usual (BAU) scenario, three future development scenarios (Table 1). As in Belize, we used the fisheries model to compare catch and revenue of the lobster fishery across these future scenarios and refine a preferred option to inform the development plan for Andros Island.

\section{Model overview}

The model used for lobster in The Bahamas was similar to the model used in Belize, with some modifications. As in Belize, we applied the model at a national scale in The Bahamas. The national scale was practical biologically, because adult lobster can make long-distance migrations and larvae are dispersed throughout The Bahamas and beyond. The national approach also reflected the scale at which changes in nursery habitats on Andros affect the lobster fishery. To capture the potential influence of management decisions at the island scale, on the national fishery, we modeled 13 regions, including Andros (Fig. 1b; Fig. A1.2 in Appendix 1). As in Belize, we assumed larvae would disperse throughout The Bahamas and settle according to the proportion of nursery habitat in each region.

Unlike Belize, we focused solely on mangroves and seagrass nursery habitats in The Bahamas. We defined nursery habitat as seagrass within $1 \mathrm{~km}$ and coastal mangroves within $250 \mathrm{~m}$ of the shore. We assumed the amount of mangrove and seagrass habitat would affect the carrying capacity of the population, because the availability of settlement and postsettlement habitat has been shown to be the greatest factor affecting recruitment potential of young lobster (Herrnkind and Butler 1986, Butler and Herrnkind 1997). In The Bahamas, fishers often deploy artificial habitats called casitas or condos to aggregate lobsters; more than 1 million casitas are estimated to be deployed throughout shallow water banks (Callwood 2016). Because of the prevalence of casitas, we assumed that adult habitat was any area on the shelf up to 200$m$ depth and not constrained to coral reefs; thus, survival was not dependent on adult habitat availability as in the Belize model. Age 2 lobsters were assumed to move from nursery to adult habitat and distribute evenly throughout contiguous shelf areas.

\section{Estimating risk to lobster habitat}

To estimate the distribution and abundance of nursery habitat under the BAU and three future development scenarios, we used the same risk assessment approach we used in Belize (Arkema et al. 2014). The approach allowed us to identify which human activities pose the greatest threat to seagrass and mangroves and how risk of habitat degradation varies spatially. For habitat data, we used 2005 30-m Landsat data for seagrass and mangroves, which had consistent coverage for the entire Bahamas. The spatial data on the seven human activities and other drivers of change (see Sustainable development planning on Andros Island) were collected from a variety of sources (Table A1.3 in Appendix 1) and through stakeholder engagement. Changes in Andros nursery habitat area under the different development scenarios were estimated based on the cumulative risk to habitats from the human activities as in Belize (Arkema et al. 2015). Because we were focused on nursery habitat and did not consider changes to adult habitat as in Belize, we used the percent change in nursery habitat to proportionally adjust $\mathrm{R}_{0}$, a parameter in the stock-recruit function related to carrying capacity (Table A1.1 in Appendix 1).

\section{Estimating catch and revenue}

Time-series data for lobster, either in the form of fishery catches or survey CPUE, were not available in The Bahamas, so we did not use the model-fitting approach that we did for Belize. We instead used information from the 2012 national stock assessment for lobster (Medley and Gittens 2012) to parameterize the stockrecruitment function in our model (see Table A1.2 in Appendix 1). We assumed a constant harvest mortality rate to isolate the effects of changes in nursery habitat. To estimate the export value of lobster catch, we used the estimated proportion of total lobster catch that reached market, i.e., the tail, and the price per processed pound of lobster (Department of Marine Resources 2014). The model was run to equilibrium and provided estimates of catch 
and revenue under the different scenarios, as well as estimates of the contribution of nursery habitats on Andros to the total production of the fishery, nationally. Lacking recent survey estimates, the model was validated based on estimated densities from historical sampling from the Little and Great Bahama Banks (Smith and van Nierop 1986).

\section{RESULTS}

Our focus is on how models and information about habitat, fish, and people were used to inform integrated management in Belize and The Bahamas. We first describe the results for lobster habitat, catch, and revenue under the alternative management scenarios. We then explore relationships between elements of the management scenarios and lobster catch and habitat to explain how the information was actually used in the planning processes.

\section{Belize}

We estimated annual catch of lobster under the current scenario (2010) as $236,000 \mathrm{~kg}(520,000 \mathrm{lb}$.) of lobster tail for a revenue of BZD 16.4 million (Fig. 2). These values are within the range of empirical data on catch and revenue for that time period (Appendix 1; Belize Ministry of Agriculture and Fisheries 2008). The productivity of the fishery depends on nearly $2000 \mathrm{~km}^{2}$ of nursery and adult habitat, including $1500 \mathrm{~km}^{2}$ of seagrass and more than $300 \mathrm{~km}^{2}$ and $100 \mathrm{~km}^{2}$ of mangroves and corals, respectively (Fig. 2).

Fig. 2. Lobster revenue and functional habitat modeled under the current scenario (2010) and three future scenarios of coastal zone use (2025) in Belize.



Extent of lobster habitat in Belize varies considerably among planning regions, with mangroves and seagrass most abundant in the Central Region, followed by Turneffe Atoll, South Northern Region (including Dangriga), and the Southern Region (Fig. A1.3 in Appendix 1; Fig. 3). Incorporating spatial differences in habitat into the model allowed us to disaggregate catch and revenue by planning region. At $90,000 \mathrm{~kg}(200,000 \mathrm{lb}$.) and nearly BZD 5 million, the Central Region (including Belize City) produced more than twice the catch of the next most productive region (Southern
Region). Limited empirical information showed the highest catch came from the region around Belize City, increasing our confidence in these estimates (Fig. A1.4 in Appendix 1).

Fig. 3. Difference, relative to 2010 levels, in lobster revenue and mangrove, coral, and seagrass functional habitat in Belize under the conservation scenario (gray), development scenario (black), and three iterations of the informed management scenario for August 2012, November 2012, and August 2013 (light to dark colors).

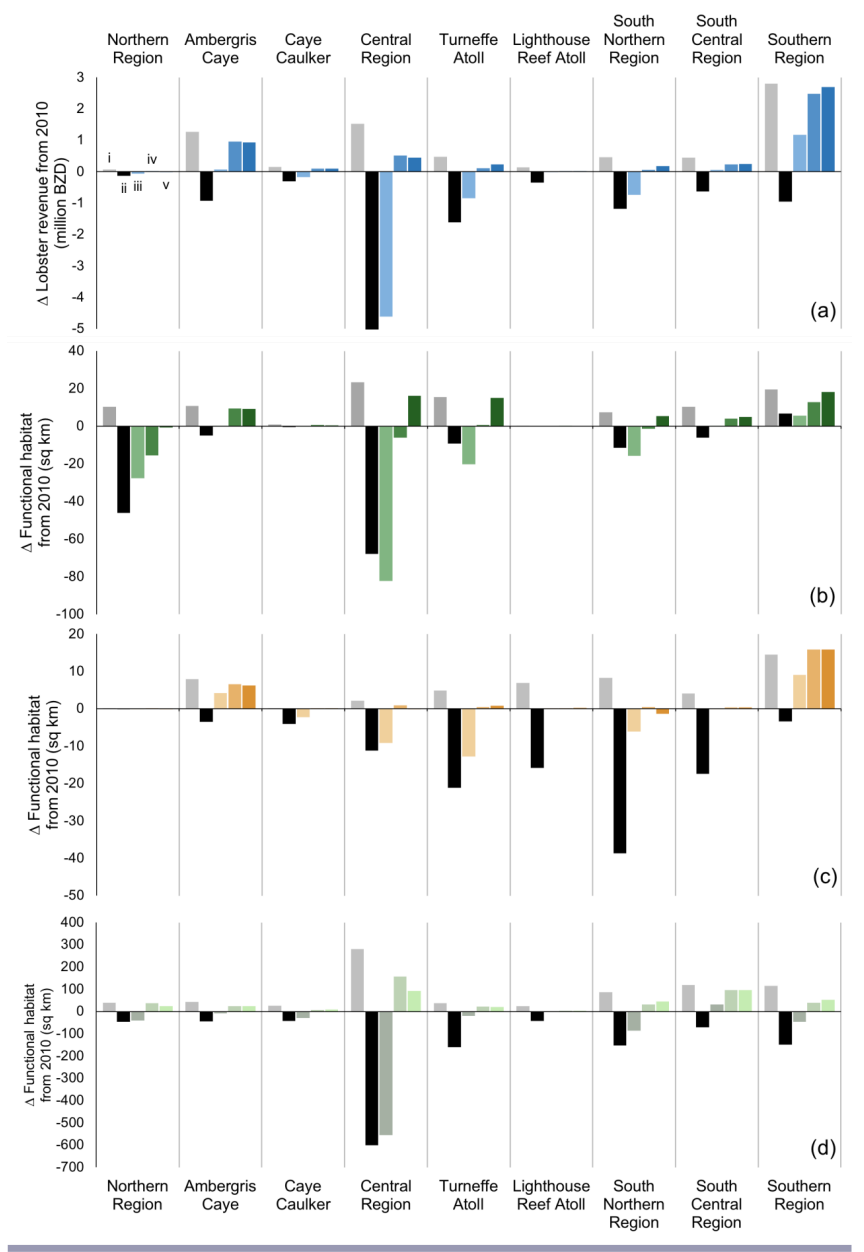

Future landings and revenue differed considerably among ICZM scenarios and as a function of lobster nursery and adult habitat. Based on the results from the habitat risk assessment for the three 2025 scenarios (Arkema et al. 2014), we estimated a 20\% increase in area of functional coral, mangrove, and seagrass habitat under the conservation and informed management scenarios, relative to the current scenario. In contrast, the area of functional mangrove habitat would be halved, and coral and seagrass reduced to $10 \%$ of their current area in the development scenario (Fig. 2). Modeled catch and revenue from the lobster fishery paralleled the changes in functional habitat. Compared with the current scenario, catch rose by $50 \%$ in the conservation scenario and dropped by nearly $100 \%$ in the development scenario. These changes in catch and revenue resulted from changes in the extent of lobster habitat in these scenarios (Fig. 2). 
The scenario eventually incorporated into the Belize ICZM plan was a version of the informed management scenario. For this scenario, we estimated $310,000 \mathrm{~kg}(680,000 \mathrm{lb}$.) in annual catch and BZD 21 million by 2025, an increase of more than $30 \%$ compared with 2010 (Fig. 2). The informed management scenario resulted from multiple iterations of revision to the zones of human activities, motivated both by stakeholder input and by the results from the lobster and other ecosystem service models (Figs. 3 and 4; Arkema et al. 2015). During the first iteration of the informed management scenario (completed in August 2012), we found dramatic decreases in the catch and revenue of lobster in several planning regions and corresponding decreases in the area of functional habitat (Fig. 3). Notably, the Central Region, which accounted for $41 \%$ of lobster catch in 2010 , experienced decreases in seagrass, mangroves, and coral under this first iteration of the scenario.

Fig. 4. Planned human activities; risk to mangrove, seagrass, and coral habitats; and resulting functional lobster habitat in the Central Region for the conservation, development, and three iterations of the informed management (August 2012, November 2012, and August 2013) scenarios in Belize.

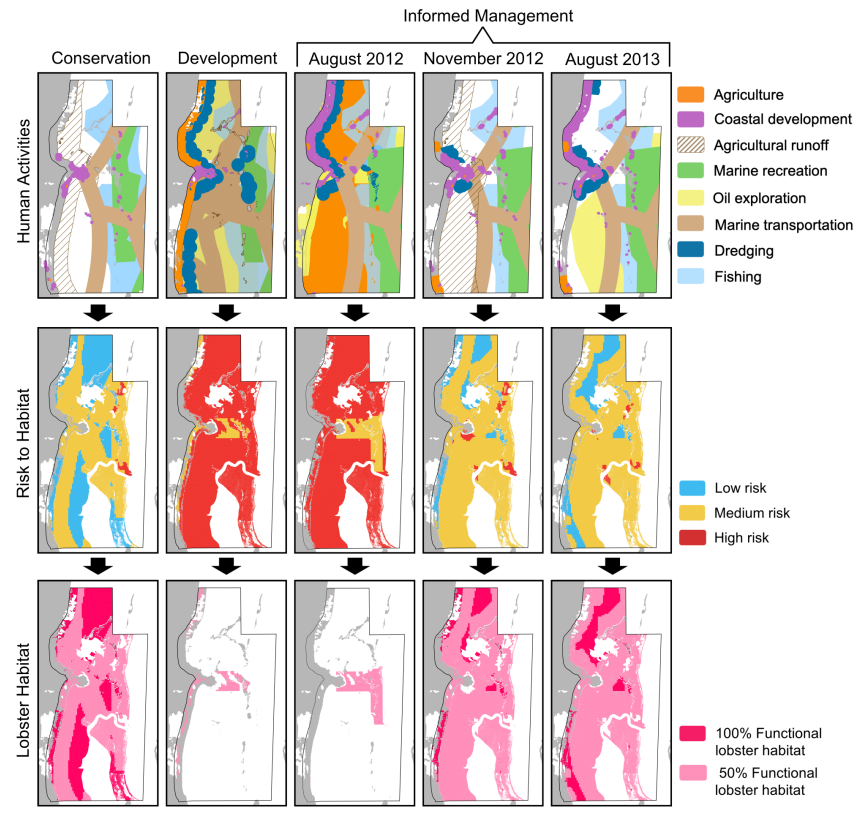

To improve catch and revenue in a transparent and efficient way, we found we could reduce the cumulative risk and increase the area of functional habitat in the Central Region by reducing the overlap between human activities and corals, mangroves, and seagrass (Figs. 3 and 4; November 2012 and August 2013 iterations). For example, we concentrated dredging activities around Belize City in the November 2012 and August 2013 versions to avoid damaging seagrass habitat elsewhere. The August 2013 iteration resulted in a more than $20 \%$ increase in the area of functional corals, mangroves, and seagrass; a corresponding $528,000 \mathrm{~kg}$ (1.164 million $\mathrm{lb}$.) increase in modeled catch; and BZD 9.9 million increase in revenue compared with the initial August 2012 version (Figs. 3 and 4). This August 2013 scenario was the version ultimately used to inform the ICZM plan.

\section{The Bahamas}

The Bahamian archipelago and its surrounding waters encompass more than $2000 \mathrm{~km}^{2}$ of seagrass and $700 \mathrm{~km}^{2}$ of mangroves. The habitats on and around Andros are particularly important for lobster, including $37 \%$ and $14 \%$ of the country's mangrove and seagrass habitat, respectively (Fig. 5). Given its abundance of nursery habitat and the assumption that lobster recruitment scales to nursery habitat, our model estimates that USD 14.5 million in lobster exports annually are attributable to the Andros nursery habitat. This contribution is greater than $20 \%$ of the total annual lobster production for all of The Bahamas (Figs. 5 and 6).

Fig. 5. (a) Modeled revenue from lobster fishery attributable to nursery habitat for each ecoregion in The Bahamas. Proportion of national mangrove (b) and seagrass (c) nursery habitat provided by Andros relative to the other regions in The Bahamas (gray portion of pie charts).



Fig. 6. Modeled revenue from lobster attributable to Andros nursery habitat and the rest of The Bahamas (bars), and functional seagrass and mangrove habitat on Andros (lines) under the current situation and four future development scenarios.

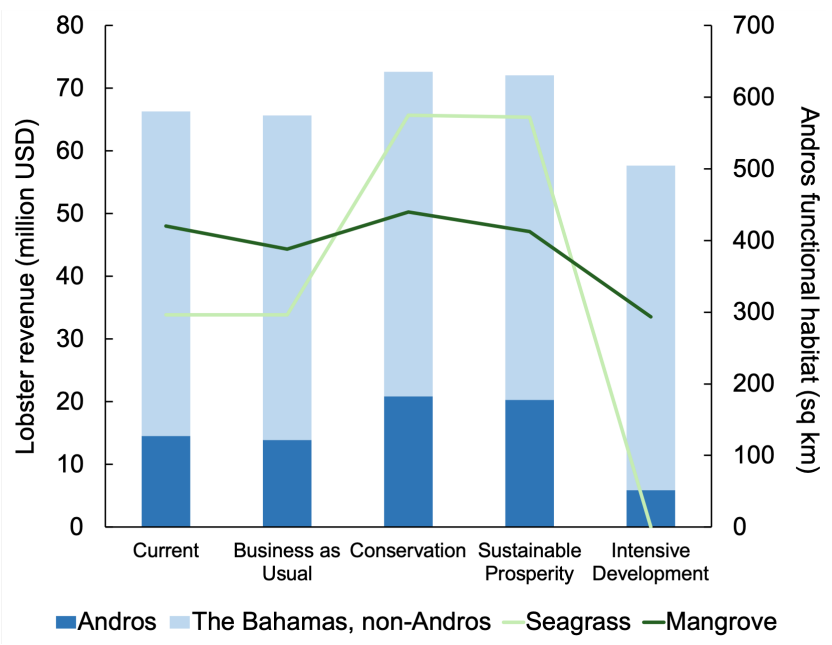


The catch and revenue of lobster attributable to Andros nursery habitat differed among future management scenarios. Under both the conservation and sustainable prosperity scenarios, catch and revenue increased by more than $740,000 \mathrm{~kg}$ (1.6 million $\mathrm{lb}$.) and USD 6 million, an increase of 50\% compared with the BAU scenario (Fig. 6). In contrast, we estimated that more than 920,000 $\mathrm{kg}(2$ million lb.) and nearly USD 8 million would be lost under the intensive development scenario. Decreases in catch and revenue resulted from increases in the spatial footprint and intensity of human activities in the intensive development scenario, which increased risk to nursery habitats. Less intensive and more concentrated development activities in the sustainable prosperity scenario posed less risk to mangroves and seagrass, leading to increases in estimated catch and revenue (Figs. 6 and 7).

Fig. 7. Human activities (top row), risk to mangrove and seagrass habitat from human activities (middle row), and functional lobster habitat in and around Andros for the current, sustainable prosperity, and intensive development scenarios, respectively. The third row maps show functional lobster habitat based on the risk results and nursery habitat classification (see Methods).

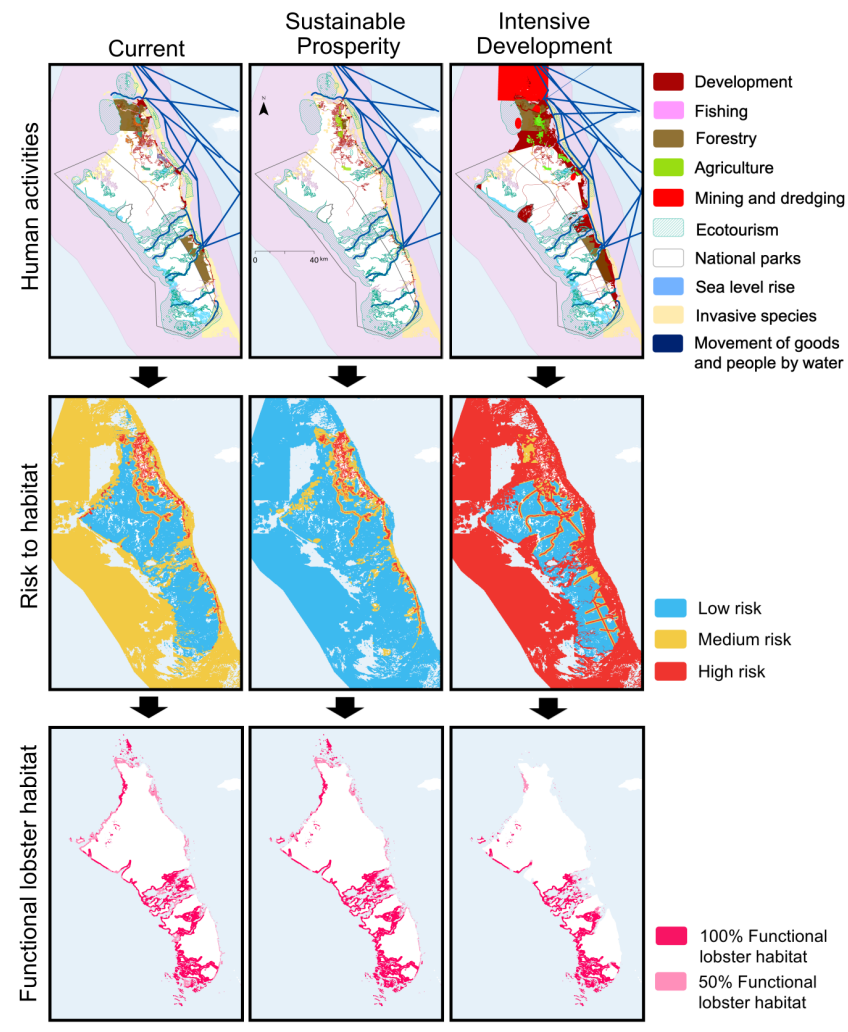

Changes in the footprint and intensity of human activities also varied among planning regions. For example, the number and extent of human activities was highest for the intensive development scenario, not only in the northern district with the highest current population, but also in the central and southern districts. In addition to expanding coastal development, the intensive development scenario assumed illegal, foreign fishing for a variety of species, which resulted in greater cumulative risk to seagrass habitat through unregulated anchoring, gear use, and other fishing practices. These changes in human activities and cumulative risk to habitats resulted in a loss of nearly $100 \mathrm{~km}^{2}$ of mangrove and $300 \mathrm{~km}^{2}$ of seagrass habitat in the intensive development scenario relative to the BAU scenario. In contrast, the sustainable prosperity scenario led to little increase in the exposure of habitats to human activities, a slight reduction in cumulative risk to habitats, and a slight increase in functional nursery habitat, by directing investments to improve management strategies and to revitalize infrastructure such as roads, without expanding their footprint. Similarly to Belize, the sustainable prosperity scenario was the result of several iterations of stakeholder engagement and modeled results. In its final version, $\sim 20 \mathrm{~km}^{2}$ of mangrove area and nearly $300 \mathrm{~km}^{2}$ of seagrass habitat was predicted to be gained, in the sustainable prosperity scenario relative to BAU (Fig. 7).

Changes in nursery habitat at the island scale have implications for returns from the lobster fishery at the national scale. The conservation and sustainable prosperity scenarios for Andros resulted in an approximately $10 \%$ increase in national catch of lobster, relative to the BAU scenario, whereas the intensive development scenario led to more than a $10 \%$ decrease. This represents a $60 \%$ decrease in Andros' contribution to national lobster productivity (Fig. 6). These quantitative results worked to communicate the connections between development decisions on Andros and national revenue. The sustainable prosperity scenario was favored for having comparable lobster revenue to the conservation scenario, while also planning for some development. As such, it became the backbone of the Andros Sustainable Development Plan (Government of The Bahamas 2017).

\section{DISCUSSION}

The importance of models for illuminating and quantifying relationships between ecosystems and people is well studied (Millennium Ecosystem Assessment 2005, Kareiva et al. 2011, Liu et al. 2015, Pascual et al. 2017), but fewer cases document how results from these models are used by scientists, stakeholders, and policy makers to collaboratively inform a decision-making process (Arkema et al. 2015, Posner et al. 2016). In coastal systems where human activities, ecosystem change, and human well-being are tightly intertwined, integrating management of fisheries with coastal development is all too rare. This oversight can lead to both undermining of fisheries management objectives and missed opportunities for designing more efficient, resilient coastal development. Coastal habitats are a critical nexus through which ecosystem benefits, such as fishery production, ecotourism, and protection from storms and sea-level rise, flow to people, and thus they can be a useful integrator of the net effects of human uses in the nearshore. We present an approach for integrating technical models with deep stakeholder engagement to demonstrate how alternative development scenarios can indirectly influence a key fisheries species through direct impacts to coastal habitats.

The quantity and quality of coastal habitat has been shown previously to influence lobster populations (Butler and Herrnkind 1997, Lipcius et al. 1997). We advance this understanding by developing and applying models that link the cumulative risk from human activities to lobster habitat to changes in catch and revenue. Our results suggest differences in fisheries productivity between scenarios for future development 
in Belize and The Bahamas and several pathways through which understanding of social-ecological systems can enhance decisions to meet multiple objectives. Demonstrating the multiple values of fish habitat to authorities in charge of land use decisions allowed us to strengthen the case for fisheries management objectives outside of a traditional fisheries management process, thus incorporating habitat for fisheries into national economic development planning (Belize Coastal Zone Management Authority and Institute 2016, Government of The Bahamas 2017).

In the case of both Belize and The Bahamas, the modeled changes in fisheries catch and revenue influenced diverse stakeholder perspectives about alternative options for development planning. In the end, the preferred management scenarios produced greater returns for fisheries than current and BAU scenarios for development. In contrast, the most intensive development scenarios resulted in dramatic drops (by approximately half) in fishery returns from the current and BAU scenarios. Quantifying habitat's role in supporting commercially valuable fisheries can help steer planners and stakeholders away from decisions that drastically harm fisheries and toward decisions that maintain or improve their productivity (Nash et al. 2016). In addition, explicitly revealing contributions of coastal habitat to fisheries can unite diverse interests around fisheries and other development objectives. In these cases, gains for fisheries also resulted in improved protection from coastal hazards and gains from tourism.

We highlight two pathways within a development planning process through which integrated modeling helped elevate fisheries management priorities: (1) scenario iteration with active stakeholder input and (2) contextualization of the implications of regional development decisions at the national scale. In Belize, iterative scenario creation (pathway 1) informed the siting of risky activities, such as oil exploration and aquaculture, away from areas where impact would be greatest on lobster fisheries and other benefits. Modeled results of each scenario iteration led to changes that reflected both stakeholder preferences for preserving vital coastal habitat and information on where ecosystems matter most for supporting fisheries. Conducting multiple cycles of modeling and stakeholder engagement allowed for coproduction of knowledge (Jasanoff 2004) about which habitat areas were of greater priority. This knowledge in turn informed where intensive activities could be shifted away from sensitive habitats, e.g., dredging in the Central Region, versus where activities such as coastal development could not be sacrificed. For instance, although the conservation scenarios in both countries provided the greatest habitat protection and lobster revenue, they never generated widespread support because of their wholesale limitation on development.

In The Bahamas, evaluation of the country's highest value fishery revealed the national implications of regional-scale development decisions (pathway 2). This highlighted for the central government, and local stakeholders, the importance of considering local habitat quality and quantity as a means to safeguard shared economic assets. Understanding Andros' contribution of local habitat to the fisheries' national total economic value shaped decision making, as exemplified by language in the Sustainable Development Master Plan for Andros
Island, which recognized that "more than $20 \%$ of the total lobster production for all of The Bahamas (nearly 4 million lbs) can be attributed to Andros nursery habitats, including wetlands, mangroves and seagrass in and around the island" (Government of The Bahamas 2017: appendix A, 10). This regional-to-national link garnered additional support from the Office of the Prime Minister for both the plan and for a development planning approach that considers not only traditional sources of revenue, but also benefits from natural systems across scales and sectors. In The Bahamas, and in Belize, the protection of habitat in the preferred management scenario also conferred gains from naturebased recreation and coastal protection (Arkema et al. 2015, Belize Coastal Zone Management Authority and Institute 2016, Government of The Bahamas 2017).

In many ways, the Caribbean spiny lobster exemplifies how models that link multiple natural and human components of a system can lead to coastal management decisions that better achieve multiple objectives. The habitat dependencies of lobster are well studied (Acosta and Butler 1997, Butler and Herrnkind 2000), and habitat availability is also relatively easily measured using satellite imagery. Moreover, because the spiny lobster is commercially valuable in both countries, the status of the fishery is important to decision makers, in contrast to other fish and invertebrates that may provide important sources of food to local communities but not necessarily support industries at multiple levels of a supply chain. Importantly, however, the spiny lobster is not an isolated case. For example, the blue crab (Callinectes sapidus) and brown shrimp (Farfantepenaeus aztecus) in the United States are fisheries that rely heavily on nursery and adult habitats often affected by coastal development (zu Ermgassen et al. 2016). Herring (Clupea pallasii) the northeast Pacific coasts of the United States and Canada rely on subtidal vegetation to lay their eggs and are also subject to coastal anthropogenic stressors (Levin et al. 2016). Our analyses show that even in relatively datapoor situations, it is possible to leverage habitat data, readily available and broadly applicable to the whole process, to model fisheries outcomes and improved decision making.

Despite its utility in informing development planning, our modeling approach has its limitations. In The Bahamas, we did not have time series of catch or survey data and thus could not estimate model parameters directly from data. In neither system did we incorporate dynamic feedbacks between habitat quality and fishing pressure. We treated mangroves and seagrasses equally in terms of larval preference and survival, although disagreement exists on preferences and survival between mangrove and seagrass (Acosta and Butler 1997, Butler and Herrnkind 2000, BrionesFourzan and Lozano-Alvarez 2001). We also lacked data for red macroalgae, which likely provide important habitat for early life stages of spiny lobster (Herrnkind and Butler 1986). Furthermore, we assumed a closed population and ignored the role of currents in influencing recruitment of larvae to different habitat areas (Callwood 2010, Garavelli et al. 2018). Larval drift models suggest widespread dispersal of larvae beyond national boundaries in the Caribbean, although with some areas of local persistence (Garavelli et al. 2018). We had no information about spatial differences in fishing effort; thus, we did not model fishing mortality as a spatially explicit process. Although we explored sensitivity of the model to several parameters, we did not conduct a thorough uncertainty analysis (Bryant et al. 2018). As 
information from both fisheries management and coastal development outcomes emerges, opportunities to better reflect uncertainty will increase for strategy adaptation and evaluations.

In conclusion, our analysis demonstrates how modeling the influence of management scenarios on fisheries catch and revenue using habitat information and knowledge of habitat-fisheries connections can improve ICZM and sustainable development planning. Modeled relationships can provide strategic information to decision makers by highlighting interconnections between fisheries and other development objectives and where synergies or trade-offs in objectives occur. The Belize and The Bahamas cases provide examples of specific kinds of information, through iteration and linking scales, that were particularly powerful for incorporating fisheries management priorities into high-level decision making for coastal development. The Anthropocene is a time of rapid environmental change and economic opportunity. As countries around the world seek to manage their natural resources for a more prosperous society, we provide support for the idea that relatively simple biophysical models can help advance coastal development planning by illustrating for scientists, stakeholders, and policy makers how fisheries outcomes are affected by decisions influencing connections among ecosystems, people, and fisheries.

Responses to this article can be read online at: http://www.ecologyandsociety.org/issues/responses. php/10630

\section{Acknowledgments:}

We are grateful for support from the Inter-American Development Bank, Google via the Tides Foundation, the Summit Foundation, and the Gordon and Betty Moore Foundation. We thank the staff at the Belize Coastal Zone Management Authority and Institute, in particular Chantalle Clark-Samuels, Samir Rosado, and Maritza Canto, and the staff in the Office of the Prime Minister of The Bahamas Development Planning Unit, in particular, Nicola VirgillRolle and Brett Lashley, for their expertise and vision for the coastal processes. In addition, we thank the many government departments, nongovernmental organizations, and individuals that provided data, expertise, and local knowledge, particularly Craig Dalgren, Lester Gittens, Ramon Carcamo, Michele Lemay, Steve Schill, and John Knowles.

\section{LITERATURE CITED}

Acosta, C. A., and M. J. Butler IV. 1997. Role of mangrove habitat as a nursery for juvenile spiny lobster, Panulirus argus, in Belize. Marine \& Freshwater Research 48:721-727. http://dx.doi. org/10.1071/MF96105

Arkema, K. K., G. Guannel, G. Verutes, S. A. Wood, A. Guerry, M. Ruckelshaus, P. Kareiva, M. Lacayo, and J. M. Silver. 2013. Coastal habitats shield people and property from sea-level rise and storms. Nature Climate Change 3:913-918. https://doi. org/10.1038/nclimate1944

Arkema, K. K., and M. Ruckelshaus. 2017. Transdisciplinary research for conservation and sustainable development planning in the Caribbean. Pages 333-357 in P. S. Levin and M. R. Poe, editors. Conservation for the Anthropocene ocean. Academic, London, UK. http://dx.doi.org/10.1016/B978-0-12-805375-1.00016-7

Arkema, K. K., G. Verutes, J. R. Bernhardt, C. Clarke, S. Rosado, M. Canto, S. A. Wood, M. Ruckelshaus, A. Rosenthal, M. McField, and J. de Zegher. 2014. Assessing habitat risk from human activities to inform coastal and marine spatial planning: a demonstration in Belize. Environmental Research Letters 9 (11):114016. http://dx.doi.org/10.1088/1748-9326/9/11/114016

Arkema, K. K., G. M. Verutes, S. A. Wood, C. Clarke-Samuels, S. Rosado, M. Canto, A. Rosenthal, M. Ruckelshaus, G. Guannel, J. Toft, J. Faries, J. M. Silver, R. Griffin, and A. D. Guerry. 2015. Embedding ecosystem services in coastal planning leads to better outcomes for people and nature. Proceedings of the National Academy of Sciences of the United States of America 112 (24):7390-7395. http://dx.doi.org/10.1073/pnas.1406483112

Barbier, E. B., S. D. Hacker, C. Kennedy, E. W. Koch, A. C. Stier, and B. R. Silliman. 2011. The value of estuarine and coastal ecosystem services. Ecological Monographs 81(2):169-193. http:// dx.doi.org/10.1890/10-1510.1

Basurto, X., E. Blanco, M. Nenadovic, and B. Vollan. 2016. Integrating simultaneous prosocial and antisocial behavior into theories of collective action. Science Advances 2(3):e1501220 http://dx.doi.org/10.1126/sciadv. 1501220

Beck, M. W., I. J. Losada, P. Menéndez, B. G. Reguero, P. DíazSimal, F. Fernández. 2018. The global flood protection savings provided by coral reefs. Nature Communications 9:2186. http:// dx.doi.org/10.1038/s41467-018-04568-Z

Belize Coastal Zone Management Authority and Institute. 2016. Belize integrated coastal zone management (ICZM) plan. Belize Coastal Zone Management Authority and Institute, Belize City, Belize.

Belize Fisheries Department. 2012. Belize Fisheries Department Capture Fisheries Unit, annual report 2011. Belize Fisheries Department, Belize City, Belize.

Belize Ministry of Agriculture and Fisheries. 2008. Annual report 2008. Belize Ministry of Agriculture and Fisheries, Belmopan, Belize.

Belize Tourism Board. 2017. Belize travel \& tourism statistics digest. Belize Tourism Board, Belize City, Belize.

Briones-Fourzan, P., and E. Lozano-Alvarez. 2001. The importance of Lobophora variegata (Phaeophyta:Dictyotales) as a habitat for small juveniles of Panulirus argus (Decapoda: Palinuridae) in a tropical reef lagoon. Bulletin of Marine Science 68(2):207-219.

Bryant, B. P., M. E. Borsuk, P. Hamel, K. L. L. Oleson, C. J. E. Schulp, and S. Willcock. 2018. Transparent and feasible uncertainty assessment adds value to applied ecosystem services modeling. Ecosystem Services 33B:103-109. http://dx.doi. org/10.1016/j.ecoser.2018.09.001

Butler, M. J., IV, and W. F. Herrnkind. 1997. A test of recruitment limitation and the potential for artificial enhancement of spiny lobster (Panulirus argus) populations in Florida. Canadian Journal of Fisheries and Aquatic Sciences 54(2):452-463. http:// dx.doi.org/10.1139/f96-281 
Butler, M. J., IV, and W. F. Herrnkind. 2000. Puerulus and juvenile ecology. Pages 276-301 in B. F. Phillips and J. Kittaka, editors. Spiny lobsters: fisheries and culture. Second edition. Blackwell Science, Malden, Massachusetts, USA. http://dx.doi. org/10.1002/9780470698808.ch15

Callwood, K. 2010. Use of larval connectivity modeling to determine settlement habitats of Panulirus argus in The Bahamas as a pre-cursor to marine protected area network planning. Thesis. University of Miami, Miami, Florida, USA.

Callwood, K. 2016. Condos, connectivity, and catch: analyzing the state of the Bahamian spiny lobster fishery. Dissertation. University of Miami, Miami, Florida, USA.

Christie, P., N. J. Bennett, N. J. Gray, T. 'Aulani Wilhelm, N. Lewis, J. Parks, N. C. Ban, R. L. Gruby, L. Gordon, J. Day, S. Taei, and A. M. Friedlander. 2017. Why people matter in ocean governance: incorporating human dimensions into large-scale marine protected areas. Marine Policy 84:273-284. http://dx.doi. org/10.1016/j.marpol.2017.08.002

Clark, W. C., T. P. Tomich, M. van Noordwijk, D. Guston, D. Catacutan, N. M. Dickson, and E. McNie. 2016a. Boundary work for sustainable development: natural resource management at the Consultative Group on International Agricultural Research (CGIAR). Proceedings of the National Academy of Sciences of the United States of America 113(17):4615-4622. http://dx.doi. org/10.1073/pnas.0900231108

Clark, W. C., L. van Kerkhoff, L. Lebel, and G. C. Gallopin. 2016b. Crafting usable knowledge for sustainable development. Proceedings of the National Academy of Sciences of the United States of America 113(17):4570-4578. http://dx.doi.org/10.1073/ pnas. 1601266113

Collie, J. S., L. W. Botsford, A. Hastings, I. C. Kaplan, J. L. Largier, P. A. Livingston, É. Plagányi, K. A. Rose, B. K. Wells, and F. E. Werner. 2016. Ecosystem models for fisheries management: finding the sweet spot. Fish and Fisheries 17:101-125. http://dx. doi.org/10.1111/faf.12093

Cook, C. N., M. B. Mascia, M. W. Schwartz, H. P. Possingham, and R. A. Fuller. 2013. Achieving conservation science that bridges the knowledge-action boundary. Conservation Biology 27 (4):669-678. http://dx.doi.org/10.1111/cobi.12050

Cooper, E., L. Burke, and N. Bood. 2009. The economic contribution of Belize's coral reefs and mangroves. World Resources Institute, Washington, D.C., USA.

Department of Marine Resources. 2014. Total fishery product price indices \& resource exports 2014. Department of Marine Resources, Nassau, The Bahamas.

Dowling, N. A., J. R. Wilson, M. B. Rudd, E. A. Babcock, D. Dougherty, and M. Gleason. 2016. FishPath: a decision support system for assessing and managing data- and capacity-limited fisheries. Pages 59-96 in T. J. Quinn II, J. L. Armstrong, M. Baker, J. Heifetz, and D. Witherell, editors. Assessing and managing datalimited fish stocks. Alaska Sea Grant, Fairbanks, Alaska, USA.

Dugan, J. E., L. Airoldi, M. G. Chapman, S. J. Walker, and T. Schlacher. 2011. Estuarine and coastal structures: environmental effects, a focus on shore and nearshore structures. Pages 17-41 in
M. J. Kennish and M. Elliot, editors. Treatise on estuarine and coastal science. Volume 8, human-induced problems (uses and abuses). Academic, Amsterdam, The Netherlands. http://dx.doi. org/10.1016/B978-0-12-374711-2.00802-0

Ehrhardt, N., R. Puga, and M. Butler IV. 2011. Implications of the ecosystem approach to fisheries management in large ecosystems. Pages 157-176 in L. Fanning, R. Mahon, P. McConney, and L. Verhart, editors. Towards marine ecosystembased management in the wider Caribbean. Amsterdam University Press, Amsterdam, The Netherlands. http://dx.doi. org/10.1515/9789048512805-014

Fanning, L., R. Mahon, P. McConney, and L. Verhart. 2011. Towards marine ecosystem-based management in the wider Caribbean. Amsterdam University Press, Amsterdam, The Netherlands. https://doi.org/10.1515/9789048512805

Food and Agriculture Organization of the United Nations (FAO). 2014. The state of world fisheries and aquaculture: opportunities and challenges. FAO, Rome, Italy.

Fujita, R., L. Epstein, W. Battista, K. Karr, P. Higgins, J. Landman, and R. Carcamo. 2017. Scaling territorial use rights in fisheries (TURFs) in Belize. Bulletin of Marine Science 93 (1):137-153. https://doi.org/10.5343/bms.2016.1002

Fujita, R., A. Tourgee, R. Carcamo, L. Epstein, T. Gedamke, G. McDonald, J. R. Wilson, and J. R. Foley. 2019. Assessing and managing small-scale fisheries in Belize. Pages 177-195 in S. Salas, M. Barragán-Paladines, and R. Chuenpagdee, editors. Viability and sustainability of small-scale fisheries in Latin America and the Caribbean. MARE Publication Series, Volume 19. Springer, Cham, Switzerland. https://doi.org/10.1007/978-3-319-76078-0_8

Fulton, E. A., A. D. M. Smith, D. C. Smith, and P. Johnson. 2014. An integrated approach is needed for ecosystem based fisheries management: insights from ecosystem-level management strategy evaluation. PLoS ONE 9(1):e84242. http://dx.doi.org/10.1371/ journal.pone.0084242

Garavelli, L., J. W. White, I. Chollett, and L. M. Chérubin. 2018. Population models reveal unexpected patterns of local persistence despite widespread larval dispersal in a highly exploited species. Conservation Letters 11(5):e12567. https://doi.org/10.1111/ conl.12567

Gopnik, M., C. Fieseler, L. Cantral, K. McClellan, L. Pendleton, and L. Crowder. 2012. Coming to the table: early stakeholder engagement in marine spatial planning. Marine Policy 36 (5):1139-1149. http://dx.doi.org/10.1016/j.marpol.2012.02.012

Government of Belize. 2000. Coastal Zone Management Act chapter 329: revised edition 2000-showing the law as at 31st December 2000. Government of Belize, Belmopan, Belize.

Government of The Bahamas. 2017. Sustainable development master plan for Andros Island. Government of The Bahamas, Nassau, The Bahamas. [online] URL: http://www.vision2040bahamas. org/media/uploads/andros master plan.pdf

Halpern, B. S., K. L. McLeod, A. A. Rosenberg, and L. B. Crowder. 2008. Managing for cumulative impacts in ecosystembased management through ocean zoning. Ocean \& Coastal Management 51(3):203-211. http://dx.doi.org/10.1016/j.

ocecoaman.2007.08.002 
Harborne, A. R., P. J. Mumby, F. Micheli, C. T. Perry, C. P. Dahlgren, K. E. Holmes, and D. R. Brumbaugh. 2006. The functional value of Caribbean coral reef, seagrass and mangrove habitats to ecosystem processes. Advances in Marine Biology 50 (5):57-189. http://dx.doi.org/10.1016/S0065-2881(05)50002-6

Hargreaves-Allen, V. 2010. An economic valuation of the natural resources of Andros Islands, Bahamas. Conservation Strategy Fund, Washington, D.C., USA.

Herrnkind, W. F., and M. J. Butler IV. 1986. Factors regulating postlarval settlement and juvenile microhabitat use by spiny lobsters Panulirus argus. Marine Ecology Progress Series 34 (1/2):23-30. http://dx.doi.org/10.3354/meps034023

Huitric, M. 2005. Lobster and conch fisheries of Belize: a history of sequential exploitation. Ecology and Society 10(1):21. http:// dx.doi.org/10.5751/ES-01319-100121

Jasanoff, S. 2004. States of knowledge: the co-production of science and the social order. Routledge, London, UK. http://dx.doi. org/10.4324/9780203413845

Kareiva, P., H. Tallis, T. Ricketts, G. Daily, and S. Polasky. 2011. Natural capital: theory and practice of mapping ecosystem services. Oxford University Press, New York, New York, USA.

Kenter, J. O. 2016. Integrating deliberative monetary valuation, systems modelling and participatory mapping to assess shared values of ecosystem services. Ecosystem Services 21B:291-307. http://dx.doi.org/10.1016/j.ecoser.2016.06.010

Kohler, M., R. Stotten, M. Steinbacher, G. Leitinger, E. Tasser, U. Schirpke, U. Tappeiner, and M. Schermer. 2017. Participative spatial scenario analysis for alpine ecosystems. Environmental Management 60:679-692. http://dx.doi.org/10.1007/s00267-017-0903-7

Kough, A. S., C. B. Paris, and M. J. Butler IV. 2013. Larval connectivity and the international management of fisheries. PLoS ONE 8(6):e64970. http://dx.doi.org/10.1371/journal.pone.0064970

Levin, P. S., T. B. Francis, and N. G. Taylor. 2016. Thirty-two essential questions for understanding the social-ecological system of forage fish: the case of Pacific herring. Ecosystem Health and Sustainability 2(4):e01213. http://dx.doi.org/10.1002/ $\underline{\text { ehs } 2.1213}$

Levin, P., and M. Poe, editors. 2017. Conservation for the Anthropocene ocean. First edition. Academic, London, UK.

Lipcius, R. N., W. T. Stockhausen, D. B. Eggleston, L. S. Marshall, Jr., and B. Hickey. 1997. Hydrodynamic decoupling of recruitment, habitat quality and adult abundance in the Caribbean spiny lobster: source-sink dynamics? Marine \& Freshwater Research 48(8):807-816. http://dx.doi.org/10.1071/ $\underline{\text { MF97194 }}$

Liu, J., T. Dietz, S. R. Carpenter, C. Folke, M. Alberti, C. L. Redman, S. H. Schneider, E. Ostrom, A. N. Pell, J. Lubchenco, W. W. Taylor, Z. Ouyang, P. Deadman, T. Kratz, and W. Provencher. 2007. Coupled human and natural systems. AMBIO: A Journal of the Human Environment 36(8):639-649.

Liu, J., H. Mooney, V. Hull, S. J. Davis, J. Gaskell, T. Hertel, J. Lubchenco, K. C. Seto, P. Gleick, C. Kremen, and S. Li. 2015. Systems integration for global sustainability. Science 347 (6225):1258832. http://dx.doi.org/10.1126/science.1258832
Masi, M. D., C. H. Ainsworth, and D. L. Jones. 2017. Using a Gulf of Mexico Atlantis model to evaluate ecological indicators for sensitivity to fishing mortality and robustness to observation error. Ecological Indicators 74:516-525. http://dx.doi.org/10.1016/ j.ecolind.2016.11.008

McDonald, G., B. Harford, A. Arrivillaga, E. A. Babcock, R. Carcamo, J. Foley, R. Fujita, T. Gedamke, J. Gibson, K. Karr, J. Robinson, and J. Wilson. 2017. An indicator-based adaptive management framework and its development for data-limited fisheries in Belize. Marine Policy 76:28-37. https://doi. org/10.1016/j.marpol.2016.11.027

Medley, P. A. H., and L. Gittens. 2012. Bahamas spiny lobster stock assessment. Department of Marine Resources, Nassau, The Bahamas.

Millennium Ecosystem Assessment. 2005. Ecosystems and human well-being: synthesis. Island, Washington, D.C., USA.

Ministry of Tourism. 2016. Frequently requested tourism statistics report. Research and Statistics Department, Nassau, The Bahamas.

Moultrie, S., E. Deleveaux, G. Bethel, Y. Laurent, V. d'Shan Maycock, S. Moss-Hackett, and R. van Anrooy. 2016. Fisheries and aquaculture in The Bahamas: a review. Food and Agriculture Organization of the United Nations, Department of Marine Resources, Nassau, The Bahamas.

Mumby, P. J., K. Broad, D. R. Brumbaugh, C. P. Dahlgren, A. R. Harborne, A. Hastings, K. E. Holmes, C. V. Kappel, F. Micheli, and J. N. Sanchirico. 2008. Coral reef habitats as surrogates of species, ecological functions, and ecosystem services. Conservation Biology 22(4):941-951 http://dx.doi.org/10.1111/ j.1523-1739.2008.00933.X

Nash, K. L., J. Bijoux, J. Robinson, S. K. Wilson, and N. A. J. Graham. 2016. Harnessing fishery-independent indicators to aid management of data-poor fisheries: weighing habitat and fishing effects. Ecosphere 7(7):e01362. http://dx.doi.org/10.1002/ecs2.1362

Ostrom, E. 2009. A general framework for analyzing sustainability of social-ecological systems. Science 325 (5939):419-422. http://dx.doi.org/10.1126/science.1172133

Pascual, U., P. Balvanera, S. Díaz, G. Pataki, E. Roth, M. Stenseke, R. T. Watson, E. B. Dessane, M. Islar, E. Kelemen, V. Maris, M. Quaas, S. M. Subramanian, H. Wittmer, A. Adlan, S. Ahn, Y. S. Al-Hafedh, E. Amankwah, S. T. Asah, P. Berry, A. Bilgin, S. J. Breslow, C. Bullock, D. Cáceres, H. Daly-Hassen, E. Figueroa, C. D. Golden, E. Gómez-Baggethun, D. GonzálezJiménez, J. Houdet, H. Keune, R. Kumar, K. Ma, P. H. May, A. Mead, P. O'Farrell, R. Pandit, W. Pengue, R. Pichis-Madruga, F. Popa, S. Preston, D. Pacheco-Balanza, H. Saarikosk, B. B. Strassburg, M. van den Belt, M. Verma, F. Wickson, and N. Yagi. 2017. Valuing nature's contributions to people: the IPBES approach. Current Opinion in Environmental Sustainability 26-27:7-16 http://dx.doi.org/10.1016/j.cosust.2016.12.006

Plagányi, É. E., A. E. Punt, R. Hillary, E. B. Morello, O. Thébaud, T. Hutton, R. D. Pillans, J. T. Thorson, E. A. Fulton, A. D. M. Smith, F. Smith, P. Bayliss, M. Haywood, V. Lyne, and P. C. Rothlisberg. 2014. Multispecies fisheries management and conservation: tactical applications using models of intermediate 
complexity. Fish and Fisheries 15(1):1-22. http://dx.doi. org/10.1111/j.1467-2979.2012.00488.x

Pomeroy, R., and F. Douvere. 2008. The engagement of stakeholders in the marine spatial planning process. Marine Policy 32(5):816-822. http://dx.doi.org/10.1016/j.marpol.2008.03.017

Posner, S. M., E. McKenzie, and T. H. Ricketts. 2016. Policy impacts of ecosystem services knowledge. Proceedings of the National Academy of Sciences of the United States of America 113(7):1760-1765. http://dx.doi.org/10.1073/pnas. 1502452113

Reed, M. S. 2008. Stakeholder participation for environmental management: a literature review. Biological Conservation 141 (10):2417-2341. http://dx.doi.org/10.1016/j.biocon.2008.07.014

Ruckelshaus, M., E. McKenzie, H. Tallis, A. Guerry, G. Daily, P. Kareiva, S. Polasky, T. Ricketts, N. Bhagabati, S. A. Wood, and J. Bernhardt. 2015. Notes from the field: lessons learned from using ecosystem services approaches to inform real-world decisions. Ecological Economics 115:11-21. http://dx.doi. org/10.1016/j.ecolecon.2013.07.009

Sharp, R., H. T. Tallis, T. Ricketts, A. D. Guerry, S. A. Wood, R. Chaplin-Kramer, E. Nelson, D. Ennaanay, S. Wolny, N. Olwero, K. Vigerstol, D. Pennington, G. Mendoza, J. Aukema, J. Foster, J. Forrest, D. Cameron, K. Arkema, E. Lonsdorf, C. Kennedy, G. Verutes, C. K. Kim, G. Guannel, M. Papenfus, J. Toft, M. Marsik, J. Bernhardt, R. Griffin, K. Glowinski, N. Chaumont, A. Perelman, M. Lacayo, L. Mandle, P. Hamel, A. L. Vogl, L. Rogers, W. Bierbower, D. Denu, and J. Douglass. 2018. InVEST 3.5.0 user's guide. The Natural Capital Project, Stanford University, Stanford, California, USA.

Smith, G. B., and M. van Nierop. 1986. Abundance and potential yield of spiny lobster (Panulirus argus) on the Little and Great Bahama Banks. Bulletin of Marine Science 39(3):646-656.

Thurlow, K. E., and M. Palmer. 2007. The Bahamas ecological GAP analysis. The Nature Conservancy, Northern Caribbean Program, Nassau, The Bahamas.

Torres, C., and N. Hanley. 2016. Economic valuation of coastal and marine ecosystem services in the 21st century: an overview from a management perspective. University of Stirling, Stirling, UK.

Verutes, G. M., K. K. Arkema, C. Clarke-Samuels, S. A. Wood, A. Rosenthal, S. Rosado, M. Canto, N. Bood, and M. Ruckelshaus. 2017. Integrated planning that safeguards ecosystems and balances multiple objectives in coastal Belize. International Journal of Biodiversity Science, Ecosystem Services and Management 13(3):1-17. https://doi.org/10.1080/21513732.$\underline{2017.1345979}$

Ward, M., H. Possingham, J. R. Rhodes, and P. Mumby. 2018. Food, money and lobsters: valuing ecosystem services to align environmental management with Sustainable Development Goals. Ecosystem Services 29A:56-69. https://doi.org/10.1016/j. ecoser.2017.10.023

Wyatt, K. H., B. Griffin, A. D. Guerry, M. Ruckelshaus, M. Fogarty, and K. K. Arkema. 2017. Habitat risk assessment for regional ocean planning in the U.S. Northeast and Mid-Atlantic. PLOS ONE 12(12):e0188776. https://doi.org/10.1371/journal. pone. 0188776 zu Ermgassen, P. S. E., J. H. Grabowski, J. R. Gair, and S. P. Powers. 2016. Quantifying fish and mobile invertebrate production from a threatened nursery habitat. Journal of Applied Ecology 53(2):596-606. http://dx.doi.org/10.1111/1365-2664.12576 


\section{Appendix 1}

Arkema, K. K., L. A. Rogers, J. Toft, A. Mesher, K. H. Wyatt, S. Albury-Smith, S. Moultrie, M. H. Ruckelshaus, and J. Samhouri. 2018. Integrating fisheries management into sustainable development planning. Ecology and Society.

\section{METHODS}

To assess fisheries outcomes of alternative scenarios for Coastal Zone Management in Belize and Development Planning in The Bahamas, we combined quantitative modeling and stakeholder engagement. Our workflow began with stakeholder driven scenarios of coastal and marine uses that we then compared by assessing cumulative risk to nursery and adult habitats using a risk assessment approach. Next we estimated the amount of lobster habitat in areas of high, intermediate, and low risk, and finally input these estimates of functional lobster habitats into the InVEST fisheries model to estimate catch and revenue of lobster under different scenarios of human use (Figure A1.1).

Steps in work flow and approach for each step

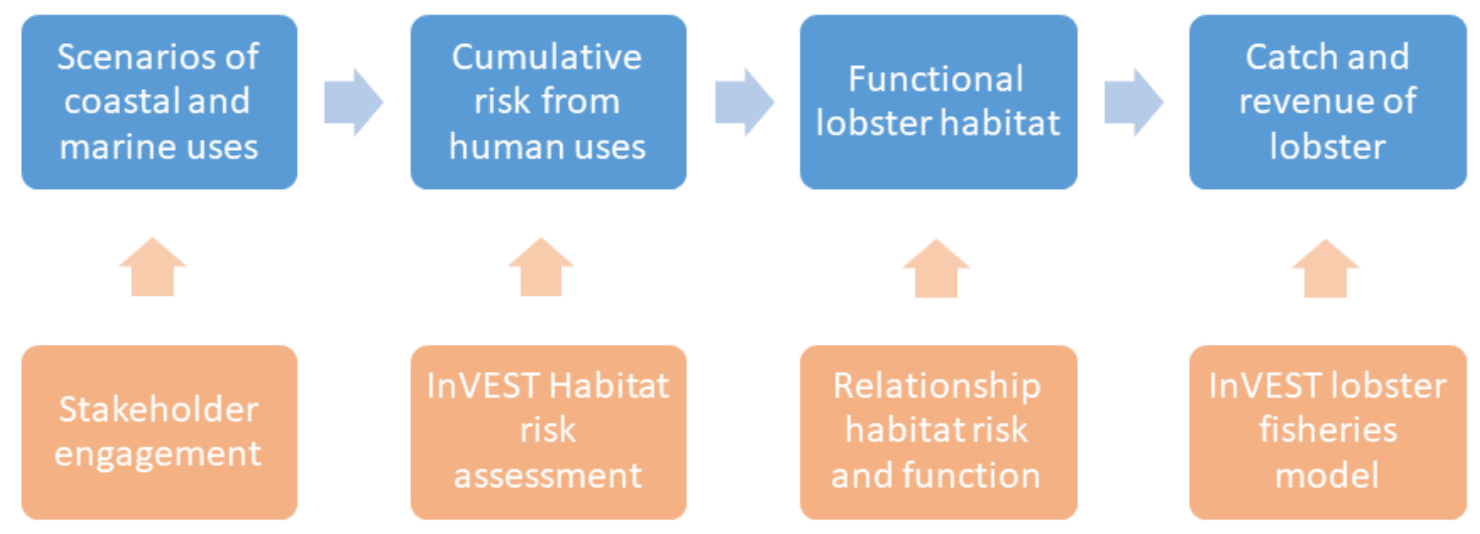

Figure A1.1: Conceptual diagram showing the steps in the workflow (blue boxes) and approach taken within each step (orange boxes).

\section{Model documentation}

To estimate how changes in habitat influence catch and revenue from the lobster fishery, we developed a model that incorporates life history, recruitment, migration, harvest, mortality, and habitat dependencies, and produces estimates of catch (as landings and export value) at national and subregional scales (Arkema et al. 2015, Ward et al. 2018). The population model is spatially explicit and age-structured with a Beverton-Holt spawner-recruitment relationship (see Equation S1 in Arkema et al. 2015). By linking recruitment or survival to habitat availability, the model can be used to assess how changes in habitat could affect productivity of the stock and resulting 
catch. Full model documentation, including inputs and data sources, is in the appendix of this paper and the supplement of Arkema et al. 2015. The model is also available for download as part of the InVEST suite of ecosystem services models (Sharp et al. 2018). The main differences between the models used in Belize and the Bahamas are summarized in Table A1.1, and more detailed descriptions appear below it.

Table A1.1 Summary of differences in model features for lobster population dynamics in Belize and the Bahamas.

\begin{tabular}{|l|l|l|}
\hline \hline \multicolumn{1}{|c|}{ Model Feature } & \multicolumn{1}{c|}{ Belize } & \multicolumn{1}{c|}{ Bahamas } \\
\hline $\begin{array}{l}\text { Influence of habitat on lobster } \\
\text { population dynamics }\end{array}$ & $\begin{array}{l}\text { Mediated via survival during } \\
\text { transitions between life stages } \\
\text { (larval to juvenile; juvenile to } \\
\text { adult) }\end{array}$ & $\begin{array}{l}\text { Mediated via maximum } \\
\text { potential recruitment at larval } \\
\text { settlement }\end{array}$ \\
\hline Dispersal to adult habitat & Distance-dependent & $\begin{array}{l}\text { Directly proportional to } \\
\text { habitat availability }\end{array}$ \\
\hline Model fitting & To catch observations & $\begin{array}{l}\text { To stock assessment } \\
\text { parameters }\end{array}$ \\
\hline
\end{tabular}

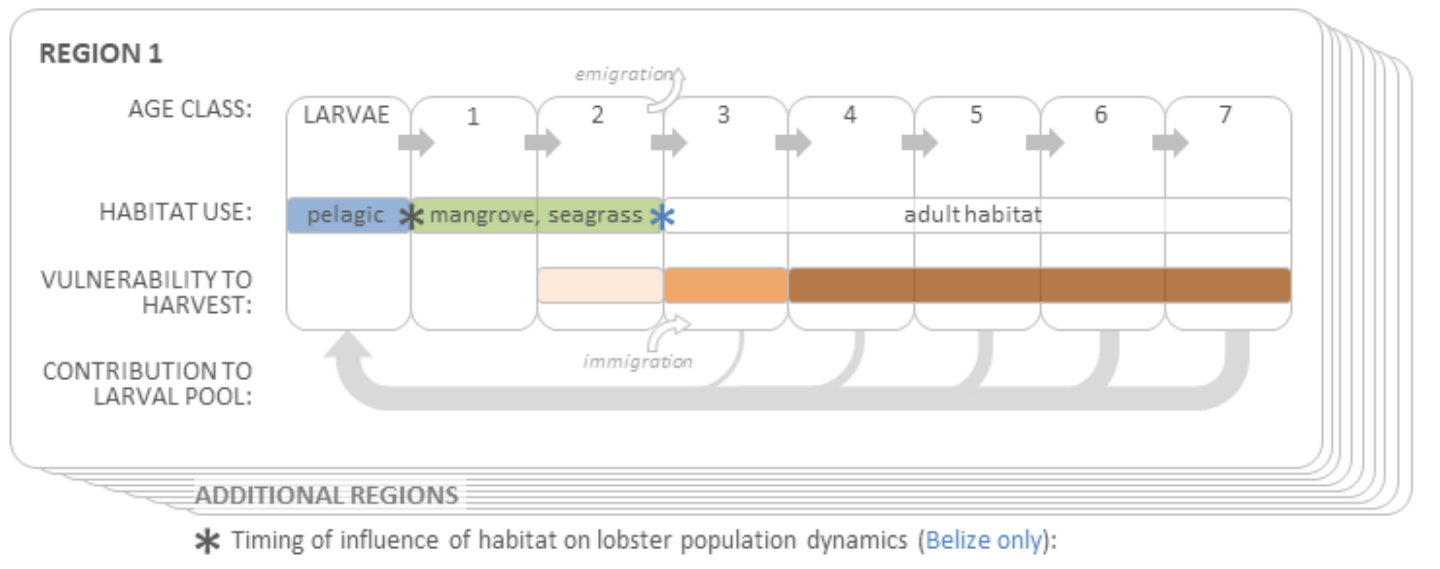

Figure A1.2 Conceptual diagram of lobster model where the asterisks indicate where habitat transitions occur that affect the lobster dynamics, either via recruitment (The Bahamas; gray asterisk) or mortality (Belize, gray and blue asterisks). 


\section{Belize}

The model details provided here complement those found in Arkema et al. 2015 Supporting Information Appendix 1 (Ecosystem service models and data/Spiny lobster model), which contains nearly complete model documentation. Equations found there are labeled below as Arkema Eqn. S1-S5, for reference. Parameter values can be found in Table A1.2 below.

\section{Life history parameters - Growth and maturation:}

We use a von Bertalanffy growth equation and a length-weight relationship to transform numbers-at-age to weight-at-age, $w_{\text {age: }}$

$$
w_{\text {age }}=a L_{\text {age }}{ }^{b}
$$

where:

- $\quad a, b$ are parameters of the von Bertalanffy growth equation

- $L_{\text {age }}$ is length-at-age

We estimated $a$ and $b$ and by minimizing the residuals between observed weights for ages 1-9 (Puga et al. 2005) and predicted weights (using $L_{a g e}$ ).

$L_{\text {age }}$ is defined as:

$$
L_{\text {age }}=L_{\infty}\left(1-\exp \left(-K\left(\text { age }-t_{0}\right)\right)\right)
$$

where:

- $\quad L_{\infty}$ is the asymptotic maximum length

- $K$ is a curvature parameter, which is proportional to the rate at which $L_{\infty}$ is reached

- $t_{0}$ is the age at which the fish has 0 length, therefore, is non-negative, or zero.

Spawner biomass is the product of numbers of lobster in each region (Arkema Eqn. S1), weight at age $\left(w_{a g e}\right)$, and maturity at age $\left(m_{\text {age }}\right)$, which is calculated using a maturity ogive governed by a logistic function:

$$
m_{\text {age }}=\left(1+\exp \left(-\phi\left(L_{\text {age }}-L_{50}\right)\right)\right)^{-1}
$$

where:

- $\quad \phi$ determines the slope of the logistic function

- $L_{50}$ is the length-at-50\% maturity

- $\quad L_{\text {age }}$ is length-at-age, defined above.

\section{Recruitment parameters}

Recruitment was modeled using a Beverton-Holt function reparameterized in terms of steepness $(h)$, average recruitment in the absence of fishing $\left(R_{0}\right)$, and spawners per recruit (SPR), which is the amount of spawning biomass produced by each recruit in an unfished population and is calculated from life history parameters (Hilborn 2010). The model gives estimated recruits (age 0 lobster) as a function of total spawning biomass $(S)$. 


$$
R=\frac{4 h R_{0} S}{R_{0} S P R(1-h)+S(5 h+1)}
$$

For recruitment, model fitting was conducted with time series of catch and CPUE (as described in full in the supplementary materials of Arkema et al. 2015).

Harvest parameters - Vulnerability to harvest:

We modeled vulnerability-at-age to harvest, $v_{a g e}$, by using the logistic function:

$$
v_{\text {age }}=1 /\left(1+\exp \left(-\left(\text { age- } a_{50}\right) * \delta\right)\right)
$$

where:

- $a_{50}$ is the age at which individuals have a $50 \%$ vulnerability to harvest

- $\delta$ determines the slope of the logistic function

The $\delta$ we chose gives the shape of the logistic function near knife-edge selectivity, meaning that very few lobster younger than 2.5 years (i.e., $a_{50}$ ) are vulnerable to fishing, whereas almost all lobster older than 2.5 years are vulnerable to fishing. This cutoff was chosen as this is the average age - modeled as described in A.1 - when a lobster reaches the minimum legal size for harvest of $75 \mathrm{~mm}$. Vulnerability to harvest was assumed to be the same across regions (Table A1.2).

Harvest rate:

Exploitation, or harvest rate, was assumed to remain constant and the same across all regions. It was calculated by dividing the modeled 2010 harvestable biomass by the observed 2010 catch (Table A1.2).

Catch to value conversion:

We calculated total pounds of harvestable lobster as the product of the numbers-at-age, weightat-age, vulnerability-at-age to harvest, and harvest rate to arrive at total pounds of catch.

Observed landings were reported as total pounds of tail meat. To compare model predictions to observations, we converted total pounds of catch by applying a conversion factor - proportion of total catch that is tail meat, from records of pounds of whole lobster landed (FAO 2001) and lobster tail production (Belize Fisheries Department Annual Report 2008) from 1947-1995 (Table A1.2).

Gross export value (\$BZ) of tails was calculated as the product of pounds of lobster tail production, proportion of tails landed that were exported in 2010 (Belize Fisheries Department 2012), and the price-per-pound for lobster tails exported in 2010 (Belize Fisheries Department 2012; Table A1.2). 
Movement parameters - Larval dispersal

Larvae were assumed to mix across all regions during their extended pelagic period, then settle in nursery habitat in direct proportion to its availability across all regions (i.e. a region with $12 \%$ of nursery habitat received $12 \%$ of recruits; also see Gariavelli et al. 2017).

\section{Migration}

Movement between regions was modeled as described in Arkema et al. 2015 (S1) when lobsters transition from age 2 to age 3 , as they move from mangroves and seagrass habitats to coral reefs (Marx and Hernkind 1986). The lobsters move from the region they have occupied at age 2 to other regions. The amount of movement is determined by an exponential decay weighted by the proportion of coral reef habitats in the region relative to the whole country. Distance was calculated as the distance between centroids of each region. The decay rate was estimated by finding the value for it that minimized the residuals between modeled biomass in each region and reports from the Belize Fisheries Department of observed catches by region (R. Carcamo, pers. Comm.; Table A1.2). Observed catch was reported by fishing areas of Belize, which are similar yet not identical to regions used in modeling. Accordingly, we reapportioned catch to model region based on areal extent of fishing areas and regions.

\section{Linking changes in habitat to lobster dynamics}

In the Belize model, lobster survival was affected by habitat availability as lobster transitioned from one habitat to another, specifically during larval settlement to nursery habitat, and during the transition to coral reefs. Survival from one age class to the next was a function of natural mortality rate, change in habitat availability during transitional ages, degree to which survival during transition depends on habitat availability, and a shape parameter for a habitat dependency logistic function (Arkema Eqn. S2). We assumed that survival during transitions between habitat was strongly dependent upon availability of habitat which could be changed in future scenarios.

Survival during transitions depended on habitat availability that in turn varied spatially based on the cumulative risk of degradation from human activities within and across ICZM scenarios. Habitat at high risk was assumed to no longer be functional for spiny lobster and was excluded from calculations of future habitat area; habitat at medium risk was assumed to be $50 \%$ functional, thus contributing half its area to future area calculations; habitat at low risk was assumed to be fully functional (Arkema et al. 2015).

\section{Model validation}

The Belizean Fisheries Department provided limited empirical information on spatial variation in catch (R. Carcamo and M. Canto, pers. comm. 2013). The fishing regions delineated by the Fisheries Department do not directly correspond to the nine ICZM planning regions, and therefore preclude a quantitative comparison of modeled versus empirical catch; however, we made a qualitative comparison across areas (Figure A1.4). 
Table A1.2 Key inputs to Fisheries Production models for spiny lobster (Belize and Bahamas)

\begin{tabular}{|c|c|c|c|c|}
\hline & \multicolumn{2}{|l|}{ BELIZE } & \multicolumn{2}{|l|}{ ВАНАMAS } \\
\hline INPUT & Value & Source & Value & Source \\
\hline \multicolumn{5}{|c|}{ Life history parameters } \\
\hline \multicolumn{5}{|l|}{ Growth } \\
\hline Length-at-age & $\begin{array}{l}L_{\infty}=180 \mathrm{~mm}, \\
K=0.24, t_{0}=0.44\end{array}$ & $\begin{array}{l}\text { de Leon González et } \\
\text { al. } 2008\end{array}$ & $\begin{array}{l}L_{\infty}=180 \mathrm{~mm}, \\
K=0.24, t_{0}=0.44\end{array}$ & \\
\hline Weight-at-age & $\begin{array}{l}\mathrm{a}=2.33 \mathrm{E}-06, \mathrm{~b}= \\
2.91\end{array}$ & Estimated; See A.1. & $\begin{array}{l}\mathrm{a}=2.33 \mathrm{E}-06, \mathrm{~b}= \\
2.91\end{array}$ & \\
\hline $\begin{array}{l}\text { Maturation } \\
\text { parameters }\end{array}$ & $\begin{array}{l}L_{50}=80 \mathrm{~mm}, \phi= \\
0.3\end{array}$ & $\begin{array}{l}\text { Little and Watson } \\
2005\end{array}$ & $\begin{array}{l}L_{50}=80 \mathrm{~mm}, \phi= \\
0.3\end{array}$ & $\begin{array}{l}\text { Little and Watson } \\
2005\end{array}$ \\
\hline Mortality rate & $M=0.36$ & $\begin{array}{l}\text { de Leon González et } \\
\text { al. } 2008\end{array}$ & $M=0.36$ & $\begin{array}{l}2012 \text { Stock } \\
\text { Assessment }\end{array}$ \\
\hline \multicolumn{5}{|c|}{ Recruitment parameters } \\
\hline Steepness & $h=0.9746$ & $\begin{array}{l}\text { Estimated; See } \\
\text { Arkema Table S4, } \\
\text { Fig. S15. }\end{array}$ & $h=0.8$ & $\begin{array}{l}2012 \text { Stock } \\
\text { Assessment }\end{array}$ \\
\hline Initial recruitment & $R_{0}=4,724,899$ & $\begin{array}{l}\text { Estimated; See } \\
\text { Arkema Table S4, } \\
\text { Fig. S15. }\end{array}$ & $R_{0}=64,524,000$ & Estimated in model \\
\hline $\begin{array}{l}\text { SPR (Spawners per } \\
\text { Recruit) }\end{array}$ & 2.64 & $\begin{array}{l}\text { Estimated using catch } \\
\text { data and life history } \\
\text { information }\end{array}$ & 2.64 & $\begin{array}{l}\text { Calculated from life } \\
\text { history }\end{array}$ \\
\hline \multicolumn{5}{|l|}{ Harvest parameters } \\
\hline Vulnerability by age & $a_{50}=2.5 ;$ delta $=10$ & Calculated; see A.3 & $a_{50}=2.5 ;$ delta $=10$ & See A.3. \\
\hline Exploitation rate & $\mathrm{Ex}=0.309$ & $\begin{array}{l}\text { See Arkema Eq. S4, } \\
\text { with } E_{x}=0\end{array}$ & $\begin{array}{l}\mathrm{Ex}=0.167 \\
(\mathrm{~F}=0.183)\end{array}$ & $\begin{array}{l}2012 \text { Stock } \\
\text { Assessment }\end{array}$ \\
\hline Price per lb (tail meat) & $P P P_{\text {tail }}=\$ 29.93$ & $\begin{array}{l}\text { Belize Fisheries } \\
\text { Department 2012; } \\
\text { See Arkema Eq. S5 }\end{array}$ & $\$ 10.86$ & $\begin{array}{l}\text { Average export } \\
\text { price (1997-2014) } \\
\text { from DMR }\end{array}$ \\
\hline $\begin{array}{l}\text { Proportion of total } \\
\text { catch that is tail meat }\end{array}$ & 0.32 & $\begin{array}{l}\text { Calculated; see A.3; } \\
\text { See Arkema Eq. S5 }\end{array}$ & 0.36 & $\begin{array}{l}2012 \text { Stock } \\
\text { Assessment }\end{array}$ \\
\hline $\begin{array}{l}\text { Proportion of tails } \\
\text { landed that were } \\
\text { exported }\end{array}$ & 0.89 & $\begin{array}{l}\text { Belize Fisheries } \\
\text { Department 2012; } \\
\text { See Arkema Eq. S5 }\end{array}$ & N/A & $\mathrm{N} / \mathrm{A}$ \\
\hline \multicolumn{5}{|l|}{ Movement parameters } \\
\hline Distance decay rate & 0.11 & Estimated; see A.4 & $\mathrm{N} / \mathrm{A}$ & $\mathrm{N} / \mathrm{A}$ \\
\hline Habitat transition & $\begin{array}{l}T_{1}, T_{3}=1 ; \text { all other } \\
T_{a}=0\end{array}$ & $\begin{array}{l}\text { Marx and Hernkind } \\
\text { 1986; See Arkema } \\
\text { Eq. S2 }\end{array}$ & $\mathrm{N} / \mathrm{A}$ & N/A \\
\hline $\begin{array}{l}\text { Habitat dependency } \\
\text { during transition }\end{array}$ & $d=1$ & $\begin{array}{l}\text { Marx and Hernkind } \\
\text { 1986; See Arkema } \\
\text { Eq. S2 }\end{array}$ & N/A & $\mathrm{N} / \mathrm{A}$ \\
\hline $\begin{array}{l}\text { habitat dependency } \\
\text { logistic function } \\
\text { shape }\end{array}$ & $\gamma=0.5$ & $\begin{array}{l}\text { Assumption based on } \\
\text { lack of information; } \\
\text { See Arkema Eq. S2 }\end{array}$ & $\mathrm{N} / \mathrm{A}$ & $\mathrm{N} / \mathrm{A}$ \\
\hline \multicolumn{5}{|l|}{ Habitat distribution } \\
\hline Seagrass & $\begin{array}{l}\text { Area of seagrass } \\
\text { within each } \\
\text { planning region }\end{array}$ & $\begin{array}{l}\text { Coastal Zone } \\
\text { Management Institute } \\
\text { of Belize (CZMI }\end{array}$ & $\begin{array}{l}\text { Area of seagrass } \\
\text { within a } 1 \mathrm{~km} \text { buffer } \\
\text { of the coastline }\end{array}$ & $\begin{array}{l}\text { Interpretation of } \\
\text { Landsat Imagery, } \\
30 \mathrm{~m}, 2005\end{array}$ \\
\hline
\end{tabular}




\begin{tabular}{|l|l|l|l|l|}
\hline & & $\begin{array}{l}\text { 1997) and } \\
\text { Mesoamerican Reef } \\
\text { Millennium study } \\
\text { (Wabnitz et al. 2007) }\end{array}$ & 20 & \\
\hline Mangroves & $\begin{array}{l}\text { Area of mangroves } \\
\text { within each } \\
\text { planning region } \\
\text { WWF }\end{array}$ & $\begin{array}{l}\text { Area of mangroves } \\
\text { within a 250m } \\
\text { buffer of the } \\
\text { coastline }\end{array}$ & $\begin{array}{l}\text { Interpretation of } \\
\text { Landsat Imagery, } \\
30 \mathrm{~m}, 2005\end{array}$ \\
\hline Coral reefs & $\begin{array}{l}\text { Area of coral reefs } \\
\text { within each }\end{array}$ & $\begin{array}{l}\text { 1999 Coastal Zone } \\
\text { Manning region } \\
\text { of Belize (CZMI) and } \\
\text { Peter Mumby }\end{array}$ & N/A & N/A \\
\hline 200m Bank area & N/A & N/A & Landsat \\
\hline
\end{tabular}

\section{The Bahamas}

The Belize model was adapted for the Bahamas, keeping much of the same form as described in Arkema et al. 2015. However, some modifications were necessary to incorporate different data sources and assumptions relevant to the decision context.

\section{Life history parameters - Growth and Maturation}

Parameters describing growth and maturity were assumed to be the same as for the Belize model, which is reasonable given the uncertainty in estimating these parameters for spiny lobster across the Caribbean (Leocadio and Cruz 2008; Table A1.2).

\section{Recruitment parameters}

We used life history information and output from the Bahamian 2012 national stock assessment for spiny lobster (Medley and Gittens, 2012) to parameterize the stock-recruitment function in our model. Steepness (h) was set to 0.8 as in Medley and Gittens (2012), and spawners per recruit (SPR) was estimated from life-table data including age-specific maturity, natural mortality, and weight at age (Table A1.2). The final parameter $\left(\mathrm{R}_{0}\right)$ was estimated by setting the harvest rate equal to that estimated in the assessment, and then solving for $\mathrm{R}_{0}$ such that the amount harvested was equal to total 2010 harvest in the assessment (Table A1.2).

\section{Harvest parameters - Vulnerability to harvest}

Lobster age 3 years and older were assumed to be vulnerable to harvest, following Medley and Gittens (2012) and based on the expected age at the minimum legal size ( 83 or $85 \mathrm{~mm}$ ). We thus used the same vulnerability function as in the Belize model, which gives near knife-edge selectivity at age 2.5 .

\section{Harvest rate}

Exploitation, or harvest rate, was assumed to remain constant and equal to that estimated in the Medley and Gittens (2012), and to be the same across all regions (Table A1.2). 
Catch to value conversion

To estimate the export value of lobster catch, we used the estimated proportion of total lobster catch that reached market (i.e. the tail) and the average export price per processed pound of lobster from 1997 - 2014 (Department of Marine Resources; Table A1.2).

\section{Movement parameters - Larval Dispersal}

Larvae were assumed to disperse throughout the Bahamas, and settle in a region in proportion to the amount of nursery habitat in that region relative to the entire Bahamas, as in the Belize model.

\section{Migration}

As in the Belize model, migration from nearshore juvenile nursery habitats (mangroves and seagrass) to offshore adult habitat occurred from age 2 to 3 . Because of the prevalence of casitas (artificial habitats deployed by fishermen to aggregate lobster), we assumed that adult habitat was any area on the shelf up to $200 \mathrm{~m}$ depth and not constrained to coral reefs. Lobster were assumed to move from nursery to adult habitat and distribute evenly throughout contiguous shelf areas. A distance-decay function was not implemented in the Bahamas.

\section{Linking changes in habitat to lobster dynamics}

For development scenarios, recruitment was assumed to be directly proportional to the amount of nursery habitat available, which was implemented by varying the parameter $\mathrm{R}_{0}$ in the stock recruit relationship. For instance, a $10 \%$ reduction in total nursery habitat would reduce $\mathrm{R}_{0}$ by $10 \%$, thus reducing the maximum potential recruitment to the stock. This is consistent with the assumption that recruitment is habitat-limited (Butler and Herrnkind 1997).

\section{Model Validation}

Given the lack of time-series data with which to fit our model, we sought to validate model estimates using available historical data. Recent survey-based estimates of lobster abundance do not exist; however, an earlier study based on widespread sampling on the banks estimated the density of lobster on the Little and Great Bahama Banks as 420 and $287 \mathrm{~kg} / \mathrm{km} 2$ respectively (Smith and van Nierop 1986). The model estimated the current density of lobster to be 365 $\mathrm{kg} / \mathrm{km} 2$, suggesting that the biological output of the model is reasonable. It is not known whether current lobster densities are greater or less than in 1986, although fishing pressure has likely increased since the 1980s. 
Table A1.3 Data originate from multiple sources, including from partners at The Nature Conservancy (TNC) and Bahamas National Trust (BNT)'

Human Use and Data Sources
Drivers of
Change

\begin{tabular}{lcc}
\hline Development & $\begin{array}{c}\text { Digitized aerial imagery } \\
\text { (TNC), stakeholder } \\
\text { drawn maps, local } \\
\text { expertise }\end{array}$ & $\begin{array}{c}\text { Spatial footprint of development, which included private, } \\
\text { residential, and commercial development, roads, lodges, } \\
\text { airports, factories, airports and more. }\end{array}$ \\
\hline $\begin{array}{l}\text { Dredging and } \\
\text { mining }\end{array}$ & $\begin{array}{c}\text { Digitized aerial imagery, } \\
\text { stakeholder drawn maps, } \\
\text { local expertise }\end{array}$ & $\begin{array}{c}\text { Spatial footprint of terrestrial quarries for sand, aragonite } \\
\text { and other minerals; and dredged marine channels for } \\
\text { transportation, often near ports }\end{array}$ \\
\hline $\begin{array}{l}\text { Nature-based } \\
\text { tourism }\end{array}$ & $\begin{array}{c}\text { TNC, Andros Island } \\
\text { Conservation }\end{array}$ & $\begin{array}{c}\text { Areas identified during stakeholder engagements } \\
\text { including areas for diving, bonefishing, bird watching, } \\
\text { kayaking etc. }\end{array}$ \\
\hline $\begin{array}{l}\text { Transportation of } \\
\text { goods and people } \\
\text { by water }\end{array}$ & $\begin{array}{c}\text { Marine Automatic } \\
\text { Identification System } \\
\text { (AIS), Stakeholders }\end{array}$ & $\begin{array}{c}\text { Buffered polylines of routes by ferries, mail boats, and } \\
\text { cargo ships. Personal transportation and fishing vessels } \\
\text { are not included. }\end{array}$ \\
\hline
\end{tabular}

Fishing Area of interest Fishing for lobster, conch, scalefish, and sponge.

Stakeholders and local experts identified that fishers use the entire area of interest.

\begin{tabular}{lcc}
\hline Forestry & Department of Forestry & $\begin{array}{c}\text { Parcel designations for conservation forests (not to be } \\
\text { harvested), forest reserves (for timber use), and protected } \\
\text { forest (that can be converted for development) }\end{array}$ \\
\hline Agriculture & $\begin{array}{l}\text { Digitized Aerial Imagery } \\
\text { (TNC), Dept of Forestry }\end{array}$ & $\begin{array}{r}\text { Spatial footprint of large-scale (e.g. for BAMSI and } \\
\text { otherwise zoned) and small-scale, agriculture. }\end{array}$ \\
\hline Invasive Species & $\begin{array}{c}\text { Andros Island } \\
\text { Conservation } \\
\text { Assessment, U.S. } \\
\text { Geological Survey }\end{array}$ & $\begin{array}{c}\text { Invasive species point data location for } \text { Melaleuca, } \\
\text { leucaena } \text {, and } \text { Casuarina buffered by 750m where density } \\
\text { was reported as sparse or dense. Lionfish are represented } \\
\text { across the coral reef, based on observations reported to }\end{array}$
\end{tabular}

USGS.

\begin{tabular}{lcc}
\hline Sea-level rise & Allen and Holding 2015 & $\begin{array}{c}\text { Not included in the current scenario. Area affected by 2m } \\
\text { of sea-level rise. Digitized from Allen and Holding } 2015 .\end{array}$ \\
\hline Protected Areas & TNC, BNT & $\begin{array}{c}\text { Protected areas as defined by the Bahamas National Trust } \\
\text { (BNT), both terrestrial and coastal }\end{array}$
\end{tabular}




\section{RESULTS}

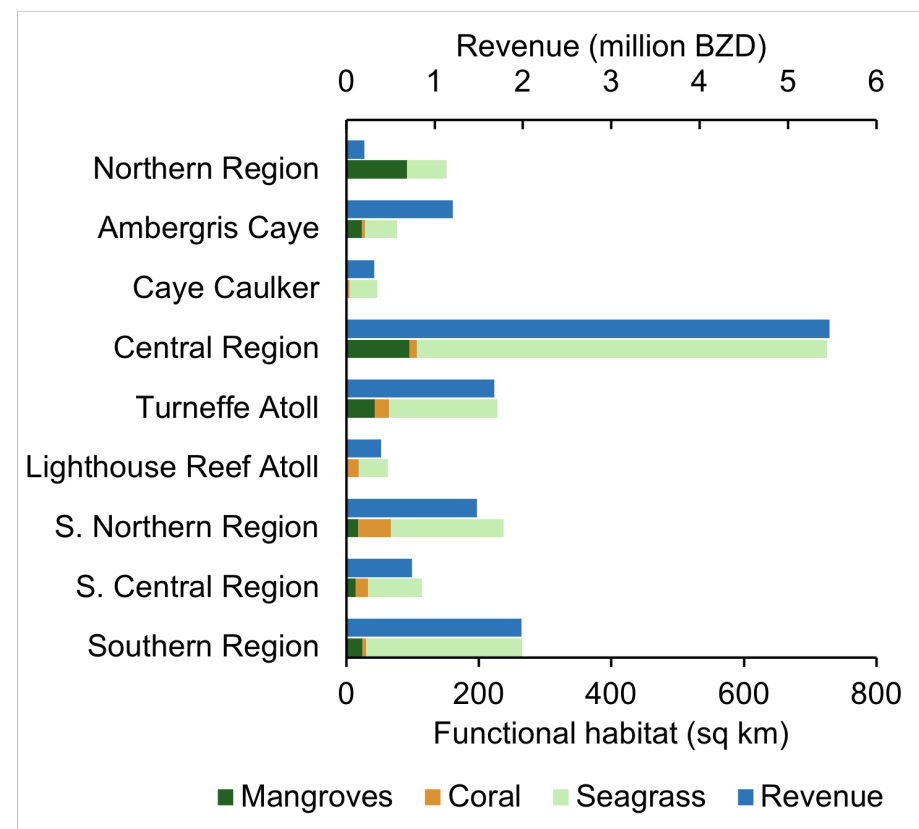

Figure A1.3 Modeled lobster revenue and area of each habitat type in Belize by planning region in 2010, the Current scenario.

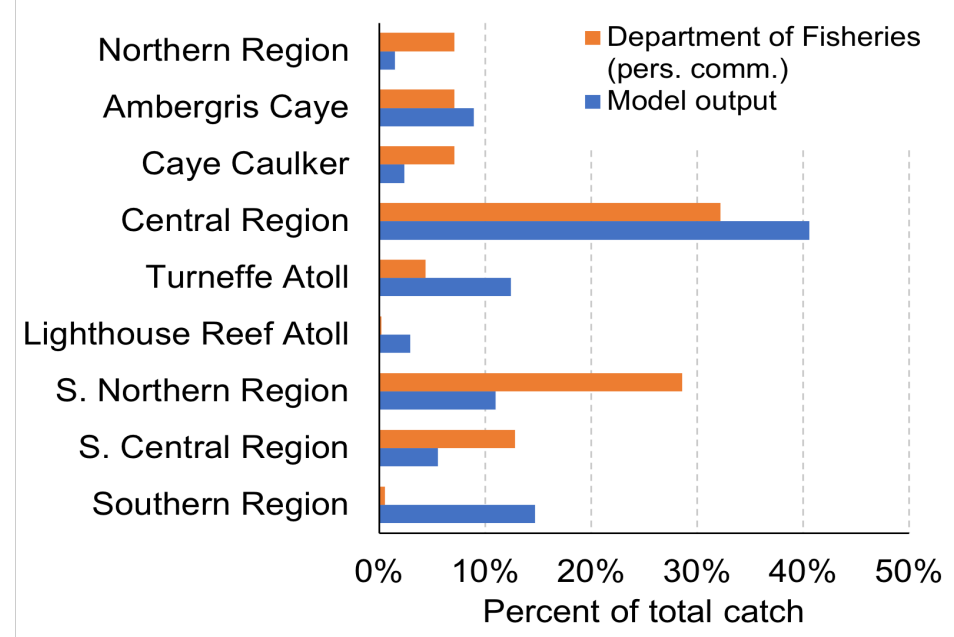

Figure A1.4 Qualitative comparison between empirical information on spatial variation in catch from the Belize Fisheries Department and modeled catch by planning region for the Current scenario. 


\section{ADDITIONAL LITERATURE CITED}

Belize Fisheries Department. 2012. Belize Fisheries Department Capture Fisheries Unit, Annual Report 2011. Belize City, Belize. February 23, 2012.

de Leon González, M.E., Carrasco, R.G., and R.A. Carcamo. 2008. A Cohort Analysis of Spiny Lobster from Belize.

FAO (Food and Agriculture Organization of the United Nations). 2001. FAO Fisheries Report No. 619. Western Central Atlantic Fishery Commission. Report on the FAO/DANIDA/CFRAMP/WECAFC regional workshops on the assessment of the Caribbean spiny lobster (Panulirus argus). Part II, Chapter 2. National report on the spiny lobster fishery in Belize; Fig. 2.4.

Leocadio, A. M. Cruz. R. 2008. Growth parameters of the spiny lobster (Panulirus argus) in the great Caribbean: A Review. Rev. Invest. Mar, 29(3), 239-248.

Little, S.A. and W.H. Watson III. 2005. Differences in the size at maturity of female american lobsters, Homarus americanus, captured throughout the range of the offshore fishery. Journal of Crustacean Biology 25(4): 585-592.

Marx, J.M., and W.F. Herrnkind. 1986. Species profiles: life histories and environmental requirements of coastal fishes and invertebrates (south Florida) - spiny lobster. U.S. Fish Wildlife Service Biological Reports 82(11.61). U.S. Army Corps of Engineers, TR EL82-4. $21 \mathrm{pp}$.

Puga, R., Hernández S., López J and León M.E. de. 2005. Bioeconomic modeling and risk assessment of the Cuban fishery for spiny lobster Panulirus argus, Fisheries Research 75: 149-163. 